\title{
Researching the Generation, Refinement, and Exploitation of Potential Opportunities
}

\section{INTRODUCTION}

Most research opportunities are characterized by uncertainty, and scholars generally have numerous options when thinking about how to contribute to and energize a field of study. In this chapter, we argue that future contributions to the field of entrepreneurship will stem from considering the entrepreneurial process as a series of steps to generate and refine opportunities through developing, engaging, and transforming communities of inquiry. In addition, this process involves a dynamic and recursive pattern of activities immersed in entrepreneurial practice that goes beyond financial goals and engages the heart as much as the mind. We believe viewing the entrepreneurial process in this way will help researchers gain a deeper understanding of how entrepreneurial action can meet some of the most challenging issues of our time, thereby enabling important contributions to the field of entrepreneurship.

First, scholars have contributed significantly to the body of research on entrepreneurial cognition focusing on individuals' beliefs about whether a specific situation is (or is not) an opportunity (e.g., Autio Dahlander, \& Fredrickson, 2013; Cornelissen \& Clarke, 2010; Gregoire, Barr, \& Shepherd, 2010; Grégoire \& Shepherd, 2012; Gruber, Macmillan, \& Thompson, 2013; Keh, Foo, \& Lim, 2002; McMullen \& Shepherd,

This chapter is based on Shepherd (2015).

(C) The Author(s) 2017

D.A. Shepherd, H. Patzelt, Trailblazing in Entrepreneurship,

DOI 10.1007/978-3-319-48701-4_2 
2006; Tang, Kacmar, \& Busenitz, 2012). Unsurprisingly, given its roots in cognitive psychology, most of this research has focused on individual-level characteristics (Baron \& Ensley, 2006; Mitchell et al., 2002; Shane, 2000; Shepherd \& DeTienne, 2005) or cognitive processes (Bryant, 2007; Busenitz \& Barney, 1997; Cornelissen \& Clarke, 2010; Grégoire et al., 2010) when explaining how people detect, understand, and/or assess possible opportunities. Future research can extend this body of research as well as enhance our understanding of entrepreneurial phenomena by taking a more interactive view of the entrepreneurial process and investigating how a community of inquiry influences the refinement of a possible opportunity and changes in the entrepreneur's mind, how potential opportunities alter a community of inquiry, and how an evolving opportunity can lead to the mutual adjustment between the entrepreneur's mind and the community of inquiry.

Second, previous research has significantly deepened our knowledge of the outcomes (Bornstein, 2004; Dean \& McMullen, 2007; Foss, Foss, Klein, \& Klein, 2007; Roberts \& Woods, 2005) and antecedents of entrepreneurial action (Krueger, 2007; McMullen \& Shepherd, 2006; Meek, Pacheco, \& York, 2010; Mitchell \& Shepherd, 2010). Scholars can further complement this research by exploring the numerous sub-activities associated with a single entrepreneurial action. More specifically, by focusing on activity as the key unit of analysis, future research can extend the literature on nascent entrepreneurship that emphasizes the series of activities involved in new venture emergence (Delmar \& Shane, 2004; Gartner, 1985; Lichtenstein, Carter, Dooley, \& Gartner, 2007) rather than the solitary act of exploiting an opportunity. Such research will help separate entrepreneurial action into its basic sub-activities and elucidate the interrelationships between activities, between an activity (or sequence of activities) and an individual's motivation to form an opportunity belief, and between an activity (or sequence of activities) and the knowledge needed to form an opportunity belief. With this research, scholars will be able to begin constructing a theory of the micro-foundations of entrepreneurial action.

Third, research has already provided strong evidence of the role cognition plays in individuals' execution of tasks essential to the entrepreneurial process, including identifying (e.g., Ardichvili, Cardozo, \& Ray, 2003; Corbett, 2005; Grégoire et al., 2010), assessing (e.g., Haynie, Shepherd, \& McMullen, 2009; Keh et al., 2002), and acting on (e.g., Autio, Dahlander, \& Frederiksen, 2013; Hmieleski \& Baron, 2008; McMullen \& Shepherd, 
2006 ) potential opportunities. In addition, research has begun to reveal how emotion influences entrepreneurs' cognitive information processing for important tasks (e.g., Baron, 2008; Foo, 2011; Shepherd, 2003; Welpe, Spörrle, Grichnik, Michl, \& Audretsch, 2012). Along these lines, research could make important contributions by building on the concept of "hot cognition" (i.e., the notion that emotions affect cognitive processing in the entrepreneurial context [Cardon, Foo, Shepherd, \& Wiklund, 2012]) to study the opposite relationship - namely, how entrepreneurial activity affects the way individuals generate emotions (both positive and negative) as they engage in challenging entrepreneurial tasks (see Gielnik, Spitzmuller, Schmitt, Klemann, \& Frese, 2015). As this research evolves, scholars can begin to investigate the reciprocal relationship between cognitions and emotions as individuals engage in entrepreneurial tasks over time.

Finally, scholars have made recent progress in the field of entrepreneurship by investigating the outcomes of entrepreneurial actions benefitting others-for instance, research on social entrepreneurship (e.g., Dacin, Dacin, \& Tracey, 2011; Dees, 1998; Mair \& Marti, 2006; McMullen, 2011 ; Peredo \& Chrisman, 2006), environmental entrepreneurship (e.g., Dean \& McMullen, 2007; Meek et al., 2010; Shepherd, Patzelt, \& Baron, 2013; York \& Venkataraman, 2010), and sustainable development (e.g., Hall, Daneke, \& Lenox, 2010; Shepherd \& Patzelt, 2011). Future scholarship that develops and extends the compassion organizing (e.g., Dutton, 2003; Dutton, Worline, Frost, \& Lilius, 2006; George, 2013; Kanov et al., 2004; Lilius et al., 2008) and prosocial motivation (e.g., Batson, 1998; De Dreu, 2006; Grant, 2007, 2008; Grant \& Berry, 2011; Grant \& Sumanth, 2009) literatures is likely to contribute significantly to these previous research lines by exploring the distinct role of entrepreneurial actions and their underlying sub-activities. More specifically, entrepreneurship researchers are particularly well suited to study how individuals can alleviate others' suffering by going beyond depending on established organizations' normal routines and developing new routines within these organizations or creating new organizations, how organizational members can alleviate non-organizational members' suffering, and how people can build new organizations in resource-devastated environments to help others. Going beyond investigating individuals' ability to act entrepreneurially to help others overcome suffering, future scholarship will likely progress this line of research by adding to and extending the concept of prosocial motivation to entrepreneurs' compassionate venturing. 
Throughout the rest of this chapter, we discuss each of these research streams in more detail. Of course, these streams are not the only potential sources of continued vitality in the field of entrepreneurship. However, we chose to focus on four sources of vitality as the foundation for future research for four primary reasons. First, the four potential sources of vitality are not inconsistent with the current entrepreneurship literature, thus enabling us to build on past research while also overcoming current and future difficulties in existing research streams. Second, irrespective of how the field is defined, opportunities and individuals' actions are essential concepts in entrepreneurship research discussions, and the focus of this chapter is in line with these critical components. Third, each source of vitality is grounded in fruitful scholarship from another field (e.g., with established theories, methods, techniques, etc.), thus enabling us to extend both the field of entrepreneurship and outside fields through combination, recombination, and creativity. Finally, research has shown that the nature of a potential opportunity is related to an individual's (or a firm's) prior knowledge. The same notion applies to us as we begin to think about future research paths and opportunities. While we will likely need to venture into unknown territory, these themes are still very much in line with the distinct knowledge of the psychology of entrepreneurship, and there are doubtless many significant opportunities within and outside these areas.

\section{A More Interactive Perspective of Entrepreneurial OpPORTUNITY}

\section{The Dominant Cognitive Psychology Perspective}

Although scholars have yet to agree on the exact nature and definition of opportunities (e.g., Davidsson, 2003, 2015; Dimov, 2011; Gartner, Carter, \& Hills, 2003; McMullen, Plummer, \& Acs, 2007; Short, Ketchen, Shook, \& Ireland, 2009), most agree that opportunities are uncertain exante (Knight, 1921) and can only really be determined post hoc. As a result, recent research on entrepreneurial opportunities has generally centered on an individual's assessment of whether a particular situation signifies an opportunity for someone (i.e., third-person opportunity) (e.g., Cornelissen \& Clarke, 2010; Grégoire et al., 2010; Grégoire \& Shepherd, 2012; Gruber et al., 2013; Shepherd \& DeTienne, 2005) and then whether it signifies an opportunity for him or her personally (i.e., firstperson opportunity) (e.g., Autio et al., 2013; Fitzsimmons \& Douglas, 
2011; Haynie et al., 2009; Keh et al., 2002; Mitchell \& Shepherd, 2010; Tang et al., 2012). Most researchers explain the formation of opportunity beliefs (first- and/or third-person) (McMullen \& Shepherd, 2006) in terms of cognitive attributes, such as prior knowledge (e.g., Shane, 2000; Shepherd \& DeTienne, 2005) and expert prototypes (Baron \& Ensley, 2006) and explore this belief formation using cognitive processes, such as heuristics (Bryant, 2007; Busenitz \& Barney, 1997), metaphors (Cornelissen \& Clarke, 2010), and structural alignments (Grégoire et al., 2010; Grégoire \& Shepherd, 2012), as the foundation. It is not surprising-given this cognitive foundation - that researchers' focus has recently centered on how individuals detect and try to decipher indicators of a potential opportunity (with social resources occasionally supporting this effort). This line of cognitive research on opportunity beliefs can likely be supplemented and extended by future research that takes a more interactive view and contributes additional insights into the refinement of potential opportunities, the transformations of communities through potential opportunities, and the mutual adjustment of both.

\section{An Interactive Perspective of the Identification and Refinement of a Potential Opportunity}

There are obviously quite a few social perspectives that could contribute to research on the formation of opportunity beliefs (e.g., collective cognition [Shalley \& Perry-Smith, 2008; West, 2007], relational capital [Hite, 2005; Yli-Renko, Autio, \& Sapienza, 2001], brokerage [Burt, 2005; Stinchfield, Nelson, \& Wood, 2013], crescive conditions [Dorado \& Ventresca, 2013], and social structure [Sorenson \& Audia, 2000]); however, particularly fruitful research is likely to come from viewing a potential opportunity as a process of social interaction between an entrepreneur and a community as opposed to an outcome of thinking on behalf of the entrepreneur. Nonetheless, if we move away from focusing on knowledge structures (e.g., schema [e.g., Corbett \& Hmieleski, 2007; Krueger, 2003], mental models [e.g., Hill \& Levenhagen, 1995; Krueger, 2007], scripts [e.g., Mitchell, Smith, Seawright, \& Morse, 2000; Smith, Mitchell, \& Mitchell, 2009], or prototypes [Baron \& Ensley, 2006]) and begin to focus on the embodiment of knowledge between an entrepreneur and a community, we are likely to gain deeper insights into the mutual adjustment between these two actors as well as the ways potential opportunities are cultivated and refined. 
While a potential opportunity can arise through an abductive process in an individual's mind (Swedberg, 2009), the idea underlying that potential opportunity is likely to stem from experiences the individual has had in the world, which must then be tested back in that context. That is, ideas "must be tested against the phenomena they are intended to unpack" (Prawat, 1995, p. 17). This testing requires a potential opportunity to be exposed "to a community whose standards allow us to correct and revise our ideas" (Pardales \& Girod, 2006, p. 302). A community of inquiry for a potential opportunity could comprise potential stakeholders who are able to comment on the potential opportunity's promise and validity (Autio et al., 2013). For instance, a community made up of other entrepreneurs, financiers, technologists, consumers, and suppliers is likely to provide a sound "reality check" for an entrepreneur pursuing a possible opportunity (Bruner, 1986; Klofsten, 2005; Kloppenberg, 1989; Seixas, 1993; Wilson, 1990). If the entrepreneur faces criticism from such a community, it is likely to raise some doubt in his or her mind, thus informing and motivating the entrepreneur to alter the potential opportunity or discard it altogether. Assuming the entrepreneur decides to continue to pursue the potential opportunity, he or she must further test it against socially verifiable facts.

Furthermore, the community of inquiry may also be transformed by interacting with the potential opportunity. For example, an entrepreneur's communication and explanation of an opportunity may alter a community member's knowledge (e.g., provide new insights into technological developments), which can influence how that member judges the opportunity (and other opportunities in the future). Alternatively, those community members who discarded the opportunity in the first place might not be available to the entrepreneur (or approached by him or her) to judge future developments of the opportunity. In contrast, when members of a community of inquiry come to the same conclusions about a potential opportunity's promise (and those conclusions are positive), there is belief in the potential opportunity (Autio et al., 2013).

\section{Potential Opportunity of the Mind and of the World}

A more interactive perspective of opportunity is in line with pragmatism and number of associated key assumptions. First, pragmatism is characterized by a world independent of individuals' minds about which people can form beliefs (Peirce, 1955). Second, in this belief system, individuals 
are only able to access the real world through their mental world (Peirce, 1955), thus meaning the two worlds are entwined (Gergen, 1994). Finally, the pragmatic perspective argues that while people search for truth, they can never truly find it. Thus, what the community of inquiry deems is truth is merely the current best opinion and is itself only temporary (Haskel, 1984; Seixas, 1993). This perspective has implications for entrepreneurship.

Namely, research on opportunities has often taken the view that opportunities are discovered or created and that creation dominates discovery in certain contexts and vice versa in other contexts (Alvarez \& Barney, 2007). An interaction perspective of opportunity, however, provides an alternative path for future studies (consistent with Dewey's [1939] characterization of mind-world dualism). Under this perspective, potential opportunities do not belong exclusively to the domain of the mind or of the world; rather, they involve the inter-relationship (i.e., mutual adjustment) of both. Indeed, as Gergen (1994, p. 129) pointed out, a vexing problem can arise when there is division and isolation between the mind and the world: "When a real world is to be reflected by a mental world and the only means of determining the match is via the mental world, the real world will always remain opaque and the relationship between the two inexplicable." Scholars can make future contributions to our understanding of opportunity by viewing potential opportunities as a conceivable means to think about and discuss the world that proves useful (through action) while simultaneously recognizing that opportunities are only tentatively held and are subject to modification as they enter and re-enter the environment.

\section{Research Opportunities from a More Interactive Perspective of Entrepreneurial Opportunity}

Community contributions to potential opportunity refinement. Following this line of thinking (i.e., viewing opportunity detection and refinement in an interactive manner), the notion of a potential opportunity should not only be considered as part of the initial creator's mind but also grounded in a community. For example, a potential opportunity that is not fully formed is likely to change after being presented to a community of inquiry as a result of that community's social forces, feedback, and criticism. In this context, many questions surrounding the community arise. What comprises a community member for a specific potential opportunity, 
including who is involved in this community, how and when do members of the community interact (if they do), how does the community come about in the first place, and how does it transform (in composition and in mind) as time passes? It could be that the nature of the community depends on the nature of the opportunity (and its dynamics), and perhaps certain communities have more success in "changing" a potential opportunity than others. It then becomes important to explore what strategies entrepreneurs use to construct, engage, and learn from communities of inquiry and why and when certain entrepreneurs are more effective in conducting these activities than others.

It is clear that a potential opportunity is likely to change after the entrepreneur has received feedback from the community; however, our understanding of the nature of this feedback and the resulting changes is still opaque. In particular, how much does a potential opportunity change after interacting with the community of inquiry and why? Perhaps the amount of change in a potential opportunity depends on the personal relationship between the entrepreneur and the community member(s) (e.g., feedback from some community members is incorporated more in the opportunity change than feedback from others). Further, it could be that the amount of opportunity change lessens over time (consistent with the notion of refinement), but perhaps changes to the potential opportunity follow a different pattern (e.g., a punctuated equilibrium model characterized by periods of incremental refinement followed by substantial change). It is interesting to consider whether opportunity changes are ever so extensive that the eventual opportunity only vaguely resembles its initial form. As with most change, perhaps there is resistance by the entrepreneur to the changes community members suggest. If so, it would be interesting to gain a deeper understanding of what effect (if any) the entrepreneur's resistance to change has on the development, refinement, and/or transformation of the potential opportunity.

Potential opportunities transforming communities of inquiry. Thus far, our discussion implies a uni-directional information flow from the community to the entrepreneur, with only the entrepreneur's mind changing from feedback about the potential opportunity. However, it is likely that the community of inquiry-and more generally the external environment-will also change from exposure to the potential opportunity. That is, as a potential opportunity is vetted, not only is there a change in the creator's mind about the potential opportunity, but there is also a change in the environment in which the potential opportunity is posi- 
tioned. Thus, from an interaction-based view, the research challenge in this context is not determining whether or when a potential opportunity is in the entrepreneur's mind versus in the world; rather, the challenge is considering both sides of the interaction at once-namely, the mind and the world are inseparably connected as a "functional unit" through a process of mutual adjustment (Dewey, 1939).

Future research can further contribute to this discussion by extending, for example, the notion of user innovation to user entrepreneurship (Shah \& Tripsas, 2007). For instance, the individual who discovered rodeo kayaking saw a potential opportunity to adapt his kayak so he could perform various tricks (e.g., enter waves in the river sideways and backwards). When others saw him doing these tricks, they asked the rider whether he could make them special kayaks as well. The potential opportunity for rodeo kayaks was further refined to include the creation of plastic hulls and center-buoyant squirt boats, which enabled "flashier tricks on steeper and more dangerous runs" and "brought media attention to the sport and a growing number of people [trying] out rodeo kayaking" (Baldwin, Hienerth, \& Von Hippel, 2006, p. 1295). Not only did the idea of rodeo kayaking change the way others viewed the sport, it also altered where the sport could take place (e.g., steeper rivers). The potential opportunity behind rodeo kayaking began in one individual's mind; however, the idea was further refined by a community of users, which itself changed because the potential opportunity was developed. This example clearly demonstrates the concept of mutual adjustment: the continual modification of a potential opportunity between the mind of the creator(s) (which changed over time) and the community of users and spectators (which also changed over time).

In line with our call for research on the ways a potential opportunity is altered through interactions with a community of inquiry, future research can significantly contribute to the field of entrepreneurship by more thoroughly investigating how and why a potential opportunity changes a community. More specifically, we can explore how changes in the nature of a potential opportunity change the associated community of inquiry in terms of its composition, collective mind, collective actions, and so on. What if we contest the implied notion that only one community exists or that the community is similar in the ways it is altered by a potential opportunity? The community may morph in one direction, but it could also split in two (perhaps based on competing opinions about the opportunity), forcing the entrepreneur to choose which branch to take (which in turn 
alters the community). If there are numerous communities for one potential opportunity, would each community be transformed differently by the opportunity, or would the potential opportunity itself become two different potential opportunities - one for each community - or both? Before we begin unpacking these questions and explore different communities or sub-communities, researchers will need to clearly define and operationalize what is meant by a community (or communities) for a potential opportunity.

Mutual adjustment between the entrepreneur's mind and the community. Fruitful research is also likely to come from the exploration of mutual adjustment-the continuous reciprocal relationship between changes in the individual's mind and transformations of the community through the development and refinement of a potential opportunity. Such research is likely to delve into the mechanisms that begin and continue the reciprocal relationship underlying the development and refinement of a potential opportunity. It is also important to explore the point at which the process of developing a potential opportunity stops such that the entrepreneur can fully exploit the refined opportunity; alternatively, perhaps, the potential opportunity continues to be changed during full exploitation (further transforming the entrepreneur's mind and the community). It could be that both alternatives are possible. That is, certain entrepreneurs and certain communities in certain situations may constantly be "updating," whereas this may not happen for other entrepreneurs, communities, and/or situations. Indeed, one could also imagine the existence of escalating "adjustment spirals" such that a change in the opportunity causes a change in the community, which triggers further changes in the opportunity and so on. Research then needs to explore how these spirals are started, perpetuated, and stopped. It will take a great deal of scholarly work to gain a deeper understanding of how this "interaction" process of developing a potential opportunity is initiated, perpetuated, and terminated. Nevertheless, we believe such research could greatly benefit the entrepreneurship field.

\section{Future Research}

Figure 2.1 provides an overview of the more interaction-based perspective of entrepreneurial opportunities we have described thus far. This interaction-based view provides countless research opportunities; however, we argue that important future research avenues worth pursuing include 
RESEARCHING THE GENERATION, REFINEMENT, AND EXPLOITATION... 27

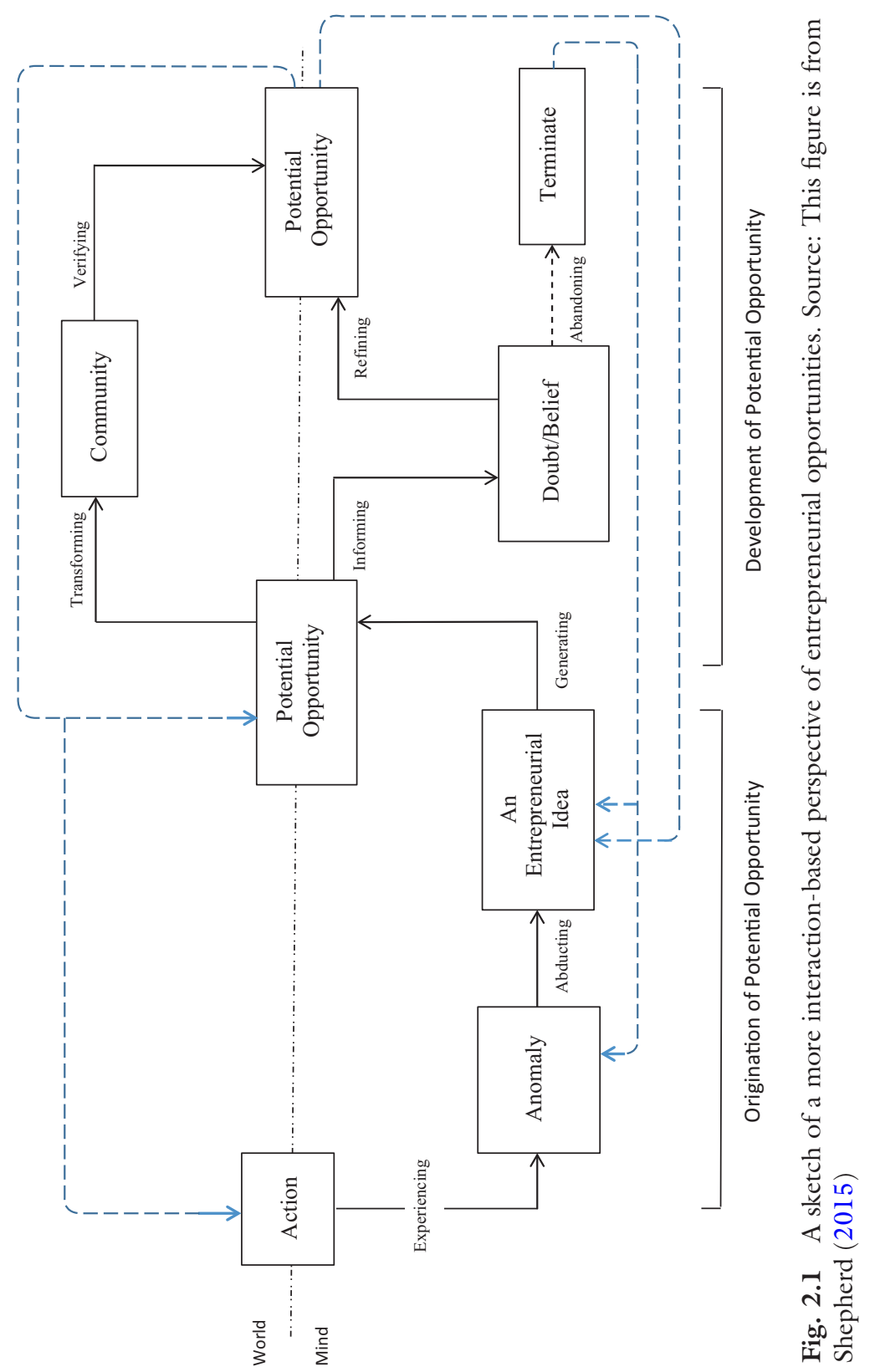


the following: (1) how does experiencing the world (through actions) lead to the creation of an entrepreneurial idea, (2) how does an entrepreneurial idea cause one to act on a potential opportunity, (3) how does acting on a potential opportunity inform an individual's opportunity belief (or reduce doubt) about the existence of an opportunity, (4) how does a community of inquiry validate a potential opportunity, (5) how does validation from a community of inquiry alter a potential opportunity and an individual's experience of the world, (6) how do changes in an individual's beliefs/ doubts refine a potential opportunity and affect the decision to abandon it, and (7) how does a potential opportunity alter a community of inquiry.

\section{Activity-Based Entrepreneurship}

\section{Toward a Theory of the Micro-Foundations of Entrepreneurial Action}

Researchers continue to have considerable interest in entrepreneurial action (Autio et al., 2013; Brettel, Mauer, Engelen, \& Kupper, 2012; McKelvie, Haynie, \& Gustavsson, 2011; Meek et al., 2010; Mitchell \& Shepherd, 2010)—or "behavior in response to a judgmental decision under uncertainty about a possible opportunity for profit" (McMullen \& Shepherd, 2006, p. 134). Such actions can lead to a variety of outcomes, including generating economic gains and/or losses for the entrepreneur (Foss et al., 2007; Klein, 2008), preserving (Dean \& McMullen, 2007) and/or destroying the natural environment (Dorfman \& Dorfman, 1993; Tietenberg, 2000), upholding (Bornstein, 2004; Roberts \& Woods, 2005 ) and/or ruining community culture (Schuler, Hashemi, \& Badal, 1998), and creating (Bornstein, 2004; Dacin et al., 2011) and/or destroying (Khan, Munir, \& Willmott, 2007) value for society.

The examples above demonstrate researchers' interest in the ultimate consequences of entrepreneurial action; however, scholars interested in nascent entrepreneurship tend to focus less on the single act of opportunity exploitation and more on the series of actions in new venture emergence (Delmar \& Shane, 2004; Gartner, 1985; Kim, Longest, \& Lippmann, 2015; Lichtenstein et al., 2007). Indeed, nascent entrepreneurs undertake numerous entrepreneurial activities, including actions that make their businesses more concrete to themselves and others. For instance, nascent entrepreneurs often look for and purchase facilities and equipment; seek and obtain financial backing, form legal entities, organize teams; and 
dedicate all their time and energy to their business (Carter, Gartner, \& Reynolds, 1996, p. 151). However, further research is needed to uncover why and when entrepreneurs undertake these activities when developing their ventures (Davidsson \& Gordon, 2012) as well as how these activities are inter-related and mutually dependent on each other.

To begin this research, it may be useful to view entrepreneurial action as a dynamic, highly iterative process of engaging in activities and experiences that both inform and are informed by a potential opportunity. When thinking of entrepreneuring as a series of activities in the entrepreneurial process, activity is the key unit of analysis. Along this line of thinking, scholars could begin to uncover the micro-foundations of entrepreneurial action by exploring key activities and their outcomes. The overall picture of the entrepreneurial process without this more detailed understanding of the micro-foundations of entrepreneurial action is more linear, granular, and disconnected from everyday life, shedding little light onto the practice of entrepreneurship. However, when the emphasis is placed on activities, the picture of the entrepreneurial process becomes more dynamic, fine grained, and immersed in everyday occurrences.

As we described in our call for an interaction-based perspective to entrepreneurship research, when a potential opportunity is refined, it produces (and reflects) changes in the entrepreneur's mind and in the community of inquiry. These changes are caused by a series of inter-related activities. For instance, if an entrepreneur is left with some level of doubt (i.e., a feeling of not knowing [Locke, Golden-Biddle, \& Feldman, 2008]) about the veracity of a potential opportunity after interacting with the community of inquiry, the entrepreneur would be motivated to inquire further. In this context, inquiry is the "activity of resolving genuine doubt in order to arrive at stable beliefs" (Locke et al., 2008, p. 908). In other words, doubt inspires the entrepreneur to undertake activities that inform (through changes in his or her mind) the refinement of the entrepreneurial idea. Thus, doubt can be seen as "nothing less than an opportunity to re-enter the present" (Shanley, 2005 , p. viii) to help create a more fertile idea (Paavola, 2004).

\section{Future Research on the Micro-Foundations of Entrepreneurial Action}

Breaking down entrepreneurial action into constituent activities. Substantial contributions to the field of entrepreneurship are likely to come from research investigating the numerous activities that make up entrepre- 
neurial action because it will provide the foundation for theorizing about and testing micro-foundation models of entrepreneurial action. For example, as Lumpkin and Dess (1996, p. 136) noted, the "essential act of entrepreneurship is new entry. New entry can be accomplished by entering new or established markets with new or existing goods or services. New entry is the act of launching a new venture, either by a start-up firm, through an existing firm, or via internal corporate venturing." Future scholarship can complement this research on new entry by focusing on the series of activities that lead to new entry-activities that start with a notion of a potential opportunity (i.e., a conjecture) — and activities that refine and transform that potential opportunity with the hope of eventual exploitation (including, in some contexts, activities associated with new venture creation). For example, the Panel Study of Entrepreneurial Dynamics (PSED) lists about 30 different activities entrepreneurs pursue at different stages of the venture-development process. In addition, future research can explore the more nuanced activities that make up broader entrepreneurial action and the connections between these activities. Doing so could have an important impact on the field because although some scholars have recognized that a potential opportunity may change over time (e.g., Dimov, 2007; McMullen \& Dimov, 2013; Sarasvathy, 2001), the activities surrounding these changes have largely been neglected. Thus far, the scholarly focus has either been on a rather fully formed entrepreneurial idea (with only minor changes, if any [Gruber et al., 2013]) or on a mindset as a precursor to these activities (e.g., effectual logic [Sarasvathy, 2001]). Shane (2000), for example, studied eight entrepreneurial individuals and teams who had discovered different opportunities to exploit three-dimensional printing. The underlying assumption in this particular research context is that individuals/teams recognize opportunities in a more or less fully formed state that is ready for exploitation. Specifically, when an entrepreneur talks about the opportunity to members of a community of inquiry, this sole explanation not only relates to what the entrepreneur initially recognized but also to what he or she assessed (Gruber et al., 2013).

Future research can further develop our understanding of the activities involved once a potential opportunity is identified throughout its continuous evaluation and refinement up to final exploitation. This approach acknowledges that a potential opportunity begins as a tentative conjecture and develops and evolves based on the entrepreneur's activities. In turn, these activities alter the nature of the initial potential opportunity. It seems likely that in many cases, a potential opportunity will change frequently 
and substantially (as opposed to infrequently and/or minimally). One way we can more fully understand these changes is by focusing on the activities that together shape the potential opportunity as well as the entrepreneur's (and the community's) belief in it. In addition, the entrepreneur's (and the community's) doubts and beliefs related to the opportunity are likely to influence these activities (and thus a theory of the micro-foundations of entrepreneurial action), to which we now turn.

The role of opportunity doubt and belief in entrepreneurial activities. Both doubt and belief are likely to stimulate entrepreneurial activities. However, we currently have a limited understanding of the roles doubt and belief play in this process. What activities are stimulated by doubt? It is important to understand what is activated to resolve doubt and how entrepreneurial activities change as doubt is settled and a firstperson opportunity belief forms. It is likely that certain activities are more likely than others to negate a belief (and possibly additional refinement of the potential opportunity) by re-introducing uncertainty and that some individuals or teams are more likely than others to undertake these activities. It could be that the pursuit of some activities is like a "double-edged sword" because they relieve doubt about some aspects of the opportunity (e.g., the market) but enhance doubt about other aspects (e.g., technological feasibility). Thus, we need to explore how certain combinations of activities help resolve doubt more effectively than other combinations or the activities independently. Moreover, a community of inquiry may impact the relationship between the pursuit of activities and the resolution of doubt about an opportunity (e.g., the community might communicate to the entrepreneur that some activities are more or less valuable for opportunity development).

As these conjectures reveal, this interaction-based view of entrepreneurship shifts the focus to the numerous activities comprising the entrepreneurial process, including those associated with probing an uncertain environment (Brown \& Eisenhardt, 1997; McGrath, 1999), combining and recombining resources to create potential opportunities (Baker, Miner, \& Eesley, 2003; Baker \& Nelson, 2005), engaging the community and responding to that engagement (Chandra \& Coviello, 2010; Haefliger, Jäger, \& Von Krogh, 2010; Shah \& Tripsas, 2007), testing a potential opportunity's validity and probability of success (Shane \& Eckhardt, 2003; Shepherd, Haynie, \& McMullen, 2012), exploiting a potential opportunity through new venture creation (Carter et al., 1996; Davidsson \& Honig, 2003; Lichtenstein et al., 2007), and so on. As the 
previous citations illustrate, entrepreneurship scholars have already blazed the initial trail in investigating some of these activities. However, in many ways, the work has only begun; we still have much to accomplish in this area.

\section{Future Research}

Figure 2.2 builds on the basic model of entrepreneurial action (McMullen \& Shepherd, 2006) to provide a sketch of a more activity-based perspective of entrepreneurial action, highlighting some of the significant elements of the discussion above. Future research on the activities underlying the materialization of opportunity beliefs will likely help scholars build a theory of the micro-foundations of entrepreneurial action. While many research paths open up by taking a more activity-based perspective of entrepreneurship, valuable future research questions worthy of exploration include the following: ( 1 ) what activities lead an individual to identify what he or she believes (or doubts) to be a third- and/or first-person opportunity, (2) how and why does an individual's prior knowledge affect the types of activities he or she engages in to form a third- and/or firstperson opportunity belief, (3) how and why does the nature of an individual's motivation impact the types of activities he or she undertakes to form a third- and/or first-person opportunity belief, (4) how does the interconnection between activities affect a third- and/or first-person opportunity belief, (5) how and why do certain activities shape an individual's prior knowledge and motivation (which can then shape ensuing activities), (6) how and why does altered knowledge in the evaluation stage influence knowledge in the attention stage for the detection of later potential thirdperson opportunities, and (7) how and why does the altered motivation of the evaluation stage influence motivation in the attention stage for the detection of later third-person opportunities.

\section{Entrepreneurship That Is More Cognitively Hot}

\section{Entrepreneurial Cognition and Emotion's Effect on These Cognitive Processes}

Researchers have long believed that individuals' cognitive abilities play an important role in driving entrepreneurial action (for reviews, see Gregoire, Corbett, \& McMullen, 2011; Mitchell et al., 2002). More specifically, 


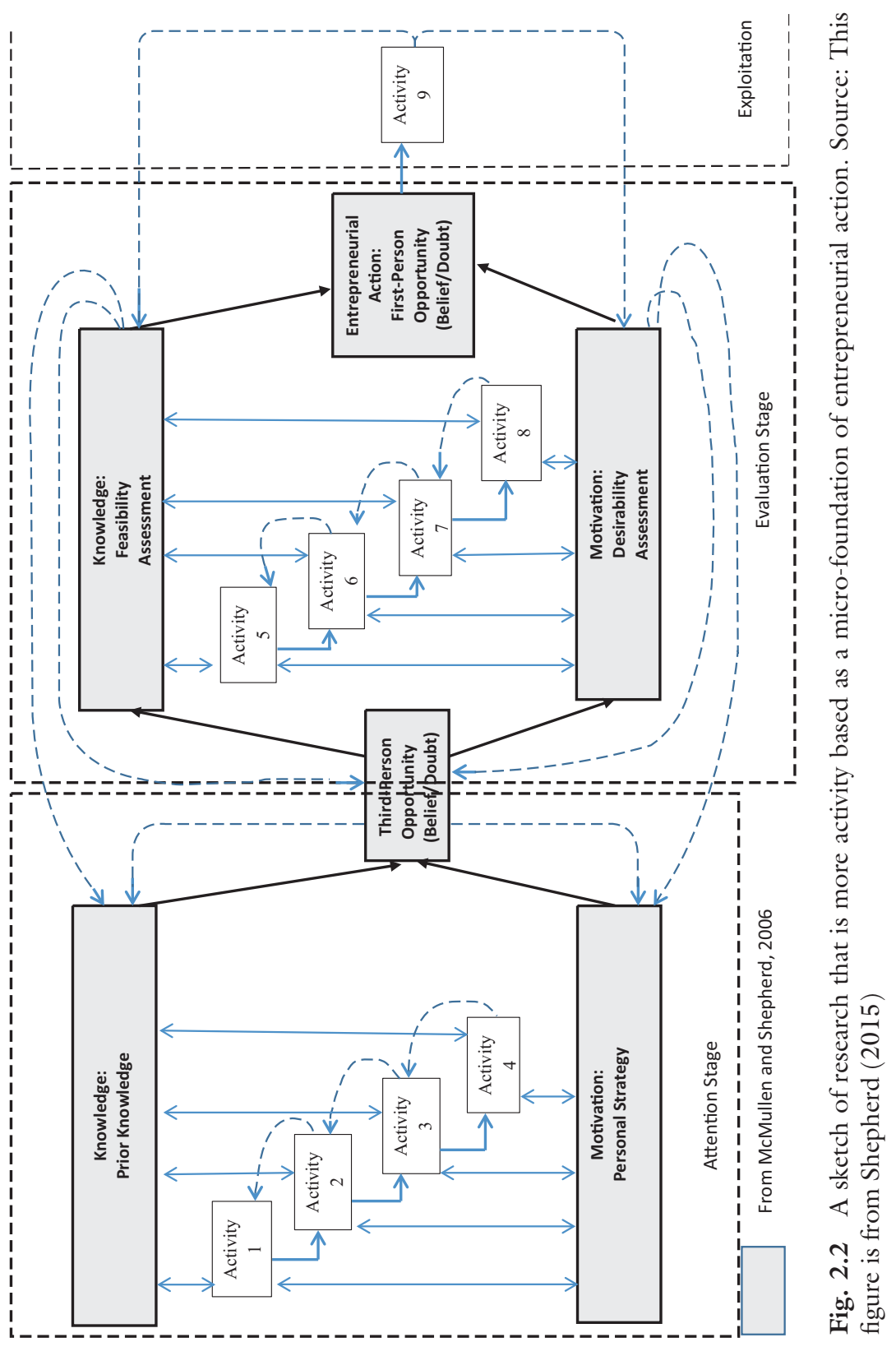


scholars hold that people are better able to navigate the entrepreneurial process (i.e., recognize, evaluate, and act on opportunities) when they have substantial knowledge (Davidsson \& Honig, 2003; Shane, 2000), have access to information (Fiet, 2007; Hoang \& Antoncic, 2003), can quickly make decisions (Eisenhardt, 1989; Forbes, 2005), and are cognitively flexible (Haynie, Shepherd, Mosakowski, \& Earley, 2010). More recently, researchers have also explored the role emotions play in the entrepreneurial process, finding that positive emotions tend to facilitate the process (Baron, 2008; Cardon, Wincent, Singh, \& Drnovsek, 2009) whereas negative emotions tend to hinder it (Shepherd, 2003; Shepherd, Patzelt, \& Wolfe, 2011). However, even with this past work, substantial opportunities remain in the field of entrepreneurship to investigate the inter-relationship between emotion and cognition.

\section{The Role of Entrepreneurial Activity in Emotions}

As a field, entrepreneurship continues to gain a deeper understanding of emotion's influence on entrepreneurial cognition. However, so far, we know little about the reverse situation-namely, entrepreneurial cognition's influence on emotions - as well as the reciprocal relationship between cognition and emotions. As a result, there are numerous opportunities for entrepreneurial scholars to make significant contributions by developing and empirically testing new theoretical perspectives that enhance our understanding of cognitive-emotion processes.

Entrepreneurial activities that generate positive emotions. Positive psychology research has shown that generating positive emotions is vital for individuals as they adjust and grow throughout their lives (Fredrickson, 1998, 2001; Seligman \& Csikszentmihalyi, 2000; Seligman, Steen, Park, \& Peterson, 2005), which has important implications for entrepreneurship research. Thus far, however, extant research in this area has primarily centered on the outcomes of positive emotions (e.g., Baron, 2008; Brundin, Patzelt, \& Shepherd, 2008; Cardon et al., 2009; Grichnik, Smeja, \& Welpe, 2010) while relatively ignoring how and why positive emotions are generated in the entrepreneurial context. Indeed, the benefits of positive emotions are likely to be especially important in this context (Baron, 2008; Cardon et al., 2012), so future research will make significant contributions to the field by investigating how individuals generate positive emotions and how these positive emotions impact ensuing cognitions, emotions, and activities throughout the entrepreneurial process. 
For example, how do the (more or less successful) development of an entrepreneurial opportunity, experiences in the entrepreneurial team, and interactions with investors and other stakeholders influence entrepreneurs' positive emotions? It could be that an entrepreneur's private and family life impact positive emotions, which in turn spill over to and influence his or her entrepreneurial activities. Moreover, as entrepreneurial action entails various different activities (Kim et al., 2015), the experience of positive emotions may serve as a trigger for the start, execution, and completion of specific entrepreneurial activities. These are only a few conjectures that scholars can address when viewing entrepreneurship through the lens of positive emotions.

Furthermore, researchers have often characterized entrepreneurs based on their emotions (e.g., highly passionate) (Cardon, Zietsma, Saparito, Matherne, \& Davis, 2005; Cardon et al., 2009) or cognitive abilities (Alvarez \& Busenitz, 2001; Ardichvili et al., 2003; Corbett, 2005; Ucbasaran, Westhead, \& Wright, 2008), and differences among individuals have been used to explain entrepreneurial action and performance. Complementing these between-individual differences, researchers can explore within-individual variance-more specifically, the ways emotions and cognitive processing change over time throughout the entrepreneurial process (for a good example, see Foo, Uy, \& Baron, 2009). For example, to what extent are positive emotions generated through positive feedback from stakeholders or the successful execution of a specific entrepreneurial activity (e.g., passing a milestone in product development, finding an attractive location for the business) sustainable over time? Research can then explore the circumstances under which entrepreneurs generate more of these positive emotions and the circumstances under which they generate fewer positive emotions.

Challenging entrepreneurial tasks and the generation of positive emotions. Changes in the environment can indicate possible opportunities (Dutton \& Duncan, 1987; Grégoire \& Shepherd, 2012; Shane, 2000). However, for entrepreneurial action to actually unfold, an individual must first respond to these signals (Dutton, 1993; Shepherd, McMullen, \& Jennings, 2007; Tripsas \& Gavetti, 2000) and then recognize that they represent a potential opportunity (Ardichvili et al., 2003; Gaglio \& Katz, 2001; Grégoire et al., 2010; Ucbasaran et al., 2008). Because opportunities are seldom overly obvious (like finding \$20 on the pavement), recognizing a possible opportunity can be quite challenging. Opportunities require one to connect a new means of supply with an exist- 
ing (yet occasionally latent) market demand, a developing market demand with a current means of supply, or a new market demand with a new means of supply (Sarasvathy, Dew, Velamuri, \& Venkataraman, 2010). At the individual level, this requires a willing and able entrepreneur "to make sense of signals of change (e.g., new information about new conditions) to form beliefs regarding whether or not enacting a course of action could lead to net benefits (for instance, in terms of profit, growth, competitive jockeying, and/or other forms of individual or organizational gains)" (Grégoire et al., 2010, p. 415). For instance, researchers have found that the cognitive processes of structural alignment have been used in the formation of opportunity beliefs (Grégoire et al., 2010), and even though they are cognitively demanding (Blanchette \& Dunbar, 2001; Catrambone \& Holyoak, 1989; Holland, Holyoak, Nisbett, \& Thagard, 1986; Keane, Ledgeway, \& Duff, 1994), they can result in mental leaps (Holyoak \& Thagard, 1995). Interestingly, when one is able to successfully finish a cognitively demanding task, he or she is likely to have positive emotions (Blood \& Zatorre, 2001; Maffei \& Fiorentini, 1995; Russell, 2003; Russell \& Milne, 1997). This discussion leads to several stimulating research questions on the role of emotions: when do entrepreneurs think that identifying potential opportunities is more or less challenging, to what extent does this opportunity identification generate positive emotions, what types of positive emotions result from identifying a potential opportunity, and how do these positive emotions (and perhaps some types of positive emotions more than others) affect ensuing cognitions and activities?

Research in the positive psychology tradition has also shown that positive emotions improve an individual's performance at cognitive tasks as well as extend individuals' scope of attention (Derryberry \& Tucker, 2006; Fredrickson \& Branigan, 2005; Isen \& Daubman, 1984); improve openness to new information (Estrada, Isen, \& Young, 1997); facilitate cognitive processes that are more creative (Isen, Daubman, \& Nowicki, 1987) and flexible (Baumann \& Kuhl, 2005; Isen \& Daubman, 1984); and produce more physical, intellectual, and social resources (Fredrickson, 2000), including generating new relationships and improving existing relationships (Fredrickson, Cohn, Coffey, Pek, \& Finkel, 2008; Waugh \& Fredrickson, 2006). If positive emotions stemming from completing a challenging entrepreneurial task improve an individual's attention, cognition, and access to resources, it is important to explore how these resulting benefits influence later activities in the entrepreneurial process. Indeed, it 
could be that certain types of positive emotions influence certain types of activities.

Further, perhaps early progress in entrepreneurial activities can even lead to a spiral of positive emotions and subsequent progress through the underlying mechanisms of increased attention, cognitive flexibility, and social resources. Under what conditions would such a spiral begin? Perhaps individuals need to complete a certain number of challenging entrepreneurial tasks (i.e., meet a specific threshold) or a certain type of task (e.g., secure funding) before generating positive emotions. If this is the case, what is that threshold or type, does it differ across individuals (and if so, how), and does it change for an individual depending on the entrepreneurial task at hand? Perhaps the threshold needed to generate positive emotions has to increase with each successive task to perpetuate a spiral, for example, to overcome habituation effects (Ashforth \& Kreiner, 2002; Belschak, Verbeke, \& Bagozzi, 2006). On the other hand, generating positive emotions may come with limitations, such as escalation of commitment, reluctance to receive community feedback, and so on.

In addition to understanding what begins and perpetuates these spirals of positive emotions and entrepreneurial progress, it is also important to explore what stops them (or perhaps even reverses them such that fewer positive emotions slow down progress, which further lowers positive emotions and so on). Certain factors may hinder progress-for example, a surprise (e.g., a negative environmental jolt); bad luck; or another task requiring immediate attention, cognition, and other resources. There could also be factors that reduce or destroy the generation of positive emotions. For instance, outside events (work or non-work related) that cause negative emotions may outweigh positive emotions in cognitive processing, such as a serious injury, the loss of a loved one, or marital problems. On the other hand, non-work-related events that generate positive emotions (e.g., marital bliss, sports team success, positive recreational experiences, etc.) could negate negative emotions at work, thus improving progress on entrepreneurial tasks.

A reciprocal relationship between challenging entrepreneurial tasks and positive emotions. By studying how different positive emotions (e.g., curiosity versus happiness) influence the mechanisms underlying progress (e.g., the ability to structurally align new means of supply with potential markets), future research can provide a deeper understanding of the reciprocal relationship between progress and positive emotions. Maybe certain positive emotions (e.g., curiosity) influence individuals' 
attention to a greater degree than the other mechanisms (e.g., creativity and building social resources), or perhaps there is another set of reciprocal relationships: as positive emotions generate a greater scope of attention, this scope of attention in turn positively influences cognitive processes (e.g., creativity, flexibility, and the generation of diverse alternatives or the identification of alternative opportunities) and access to social resources. As these conjectures reveal, there are fruitful research prospects to explore the inter-relationships between progress in entrepreneurial tasks and positive emotions as well as between the attentional, cognitive, and resource mechanisms resulting from positive emotions following progress on entrepreneurial tasks.

Challenging entrepreneurial tasks and the generation of negative emotions. As discussed above, making progress on challenging tasks tends to lead to positive emotions. However, entrepreneurs may not always feel like they are making progress (Kim et al., 2015; Kuratko, Hornsby, \& Covin, 2014). When this occurs, it is important to explore the emotional consequences that result from this lack of progress. It could be that the individual simply does not generate positive emotions, in which case the advantages of positive emotions (i.e., broadened attention, greater creativity, and enhanced access to social resources) for effectively engaging in entrepreneurial tasks do not materialize. Further, perhaps experiencing high levels of certain positive emotions has negative performance implications. For example, when entrepreneurs feel high levels of satisfaction about progress already made, they might become reluctant to invest additional effort and "lay back" and bask in achieved glory, which can diminish future progress and performance. Moreover, feelings of hope might result in overoptimism and biased evaluations of a product or venture's future potential, leading to inappropriate investment and resource-allocation decisions.

However, a lack of progress on entrepreneurial tasks can also generate negative emotions (Shepherd, Patzelt, Williams, \& Warnecke, 2014), which likely has detrimental effects on attention, cognitive flexibility, and creativity as well as socially isolates the individual (Fredrickson, 2001; Fredrickson, Mancuso, Branigan, \& Tugade, 2000; Shepherd et al., 2011). This type of situation could trigger a negative spiral such that the lack of progress leads to negative emotions that in turn hinder progress, which then generates further negative emotions and so on. While entrepreneurship scholars are generally interested in exploring success (and thus tend to concentrate on positive spirals of positive emotions), it is also important to study individuals' failure to progress on important entrepre- 
neurial tasks. For instance, scholars could investigate the inter-relationship between negative emotions and attentional scope, creativity, and social resources. Perhaps certain negative emotions or levels of specific negative emotions can facilitate progress on an entrepreneurship task. If so, what are the mechanisms underlying this relationship, and under what conditions do they operate? For example, it could be that some negative emotions (e.g., fear of failure) are needed to make an entrepreneur pay attention to a focal task and act on it. If this is the case, then we need to understand how much attention is necessary, and how much is too much. Also, assuming individuals are heterogeneous, some people are likely more able to function at a certain level of negative emotion while others become dysfunctional at the same level. Thus, how does the "maximum" tolerable level of certain negative emotions differ across entrepreneurs?

Some argue that positive emotions negate negative emotions (Fredrickson, 2001; Fredrickson et al., 2000), but research has shown that people can experience both highly positive and highly negative emotions at the same time. What effect does this ambivalence toward a specific entrepreneurial task (experiencing both highly negative and highly positive emotions [Schneider et al., 2013]) have on the cognitions needed for that entrepreneurial task and the task's influence on successive tasks and activities? For example, entrepreneurs exit their businesses for different reasons, one of which could be because they successfully achieved their goals (e.g., selling their business for a large capital gain). While this successful exit is likely to lead to positive emotions, negative emotions are also likely to arise (e.g., having to end relationships with the business and employees). On the other hand, exiting a failing business is likely to cause feelings of grief; however, these negative feelings are likely to coincide with feelings of relief that a troubling situation (giving the business "away") has come to an end. These examples lead to several interesting questions: when can entrepreneurial events lead to highly positive and highly negative emotions at the same time, what combinations of specific positive and negative emotions are possible, how do these (combinations of) emotions evolve independently and conjointly as time passes, and how do the levels and combinations of certain positive and negative emotions depend on the specific situation (e.g., selling a successful business or ending an entrepreneurial project perceived as "creeping death" [cf. Shepherd et al., 2014])? Entrepreneurship scholars can also explore why some entrepreneurs (more than others) are able to exploit the benefits of both positive and negative emotions while reducing their costs. 


\section{Future Research}

Figure 2.3 offers an overview of a more cognitively hot perspective of entrepreneurship. Like the previous research streams we have discussed, there are many possible opportunities from taking a more cognitively hot perspective. However, the following are particularly important future research avenues worth investigating: (1) how does cognitive functioning influence progress on a challenging entrepreneurial task; (2) how and why does progress on a challenging task lead to positive and/or negative emotions, and how are the levels of those reactions affected; (3) how and why do emotional reactions to progress on an entrepreneurial task affect continued cognitive functioning on that task and/or other tasks; (4) how do emotional reactions to progress on an entrepreneurial task influence one's choice to undertake challenging tasks; and (5) beyond progress on a challenging task, what other factors (work and non-work related) cause positive and/or negative emotional reactions, and what impact do they have on the entrepreneurial process?

\section{Entrepreneurship Research That Is More Compassionate and Prosocial}

\section{Heterogeneous Motivations to Investigate Entrepreneurially Generated Gains}

People are motivated to engage in the entrepreneurial process for different reasons, which is important when determining the suitability of a study's outcomes. For example, people more or less want to "do good," and entrepreneurship scholars are no exception. Using a liberal interpretation of what "gain" means, entrepreneurship scholars have conducted research that deepens our understanding of how entrepreneurial action can help individuals and communities (e.g., Dacin et al., 2011; Dees, 1998; Mair \& Marti, 2006; McMullen, 2011; Peredo \& Chrisman, 2006). Some scholars are particularly interested in the natural environment and have investigated why some entrepreneurs create products and technologies that conserve the natural world (Dean \& McMullen, 2007; Meek et al., 2010; York \& Venkataraman, 2010) while others opt to pursue opportunities that harm nature (Shepherd et al., 2013). As we continue to explore social and sustainable entrepreneurship, we will uncover new ways entrepreneurial action helps and also burts people, communities, and the natural envi- 


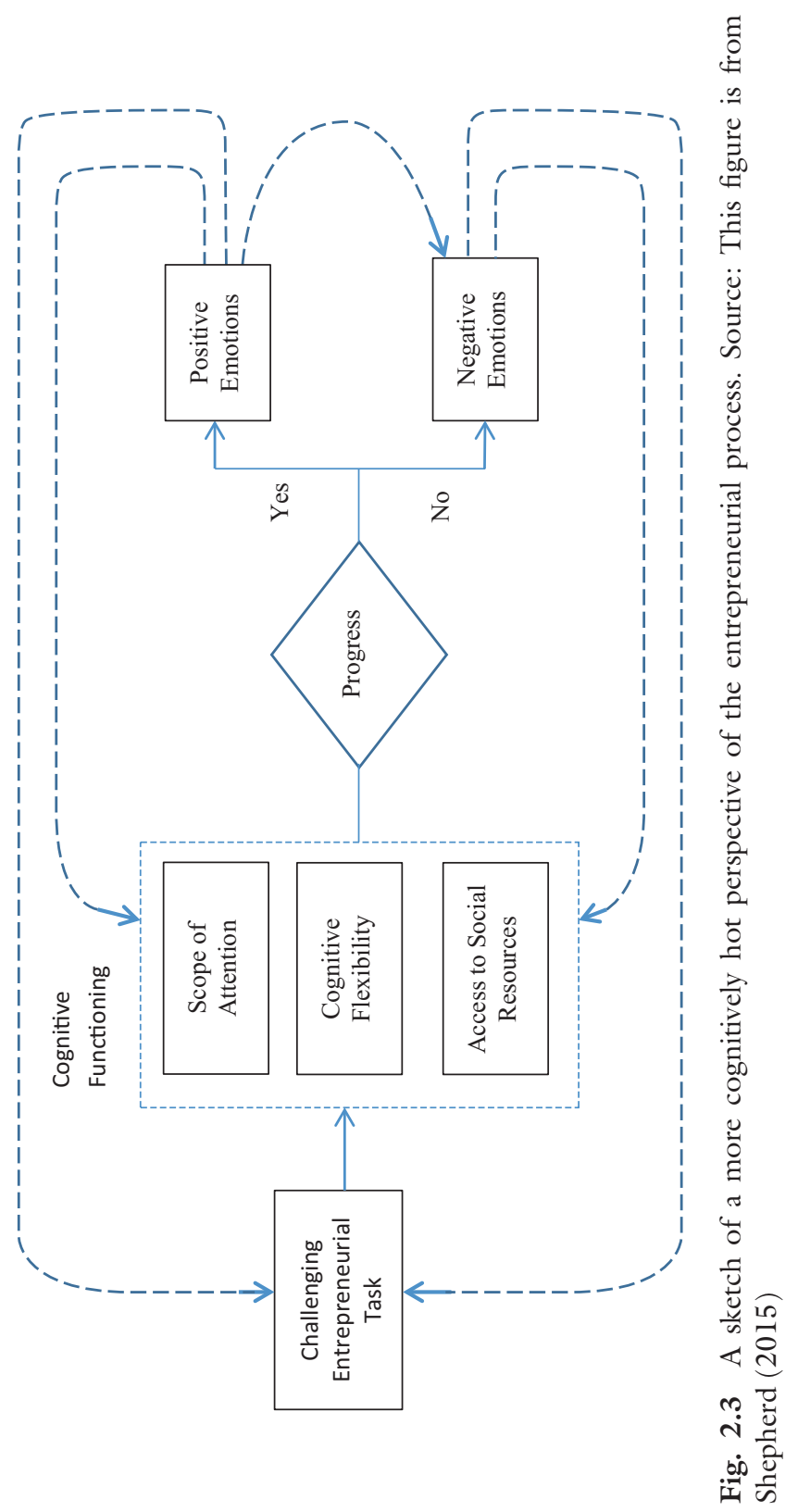


ronment. In line with our comments earlier regarding the unique domain of entrepreneurship, although discussions about the specific definitions of "social entrepreneurship," "sustainable entrepreneurship," and "environmental entrepreneurship" are stimulating (as an example, see a review of multiple definitions of social entrepreneurship by Zahra, Rawhouser, Bhawe, Neubaum, \& Hayton, 2008), these discussions should not become a perpetual debate that restricts or destroys interesting research because a study does not correspond to a pre-specified category of "sustainable," "social," or "environmental" entrepreneurship. By being more flexible about the boundaries of topics within the entrepreneurship field, we provide the space for scholars to explore these themes more freely, thus opening up the field to contributions that can expand our understanding of entrepreneurial phenomena (which, over time, might also converge into a commonly accepted definition of the field of interest).

\section{Compassion Organizing}

Positive psychology research has improved our understanding of how to alleviate people's suffering (e.g., Dutton, 2003; Dutton, Workman, \& Hardin, 2014; Dutton et al., 2006; George, 2013; Kanov et al., 2004; Lilius et al., 2008). A subset of this research has studied compassion organizing, "a collective response to a particular incident of human suffering that entails the coordination of individual compassion" and recognizes that the structures and routines an organization uses for normal work can be repurposed to alleviate a member's suffering (Dutton et al., 2006, p. 62). Suffering, or "the experience of pain or loss that evokes a form of anguish that threatens an individual's sense of meaning about his or her personal existence" (Dutton et al., 2006, p. 60; see also Sutcliffe \& Vogus, 2003), can be caused by a number of factors, such as personal tragedies, work-related events, and disasters (Armstrong, 2011; Frost, 2003; Rynes, Bartunek, Dutton, \& Margolis, 2012). Organizations are particularly well positioned to respond compassionately to member suffering. More specifically, through existing relationships with organizational members, organizations are able to collectively identify a member's suffering, feel that member's pain, and respond by repurposing current routines to lessen that member's suffering (Dutton et al., 2006; Kanov et al., 2004; Lilius, Worline, Dutton, Kanov, \& Maitlis, 2011; Rynes et al., 2012).

While much research has already been done on compassion organizing, scholars can add to and expand positive organizational research to 
deepen our understanding of how entrepreneurial action can ease human suffering. The majority of research on compassion organizing thus far has taken a positive organizational perspective. Unsurprisingly, this research stream has largely assumed the existence of a firm, focusing on the ways firms use normal routines to respond to members' pain (e.g., Dutton et al., 2006). While this research has provided an important foundation, entrepreneurship scholars can make important contributions to this line of work by investigating compassion organizing above and beyond the assumptions of an existing organization and actions limited by existing routines. Indeed, the contexts in which human suffering occurs are likely to be profoundly different from an established organization with normal routines, processes, and procedures. Furthermore, past research on compassion organizing has centered on the alleviation of buman suffering. However, entrepreneurship scholars (and perhaps compassion organizing scholars) are well positioned to broaden their view and explore suffering in terms of humans, animals, communities, the natural environment, and so on (e.g., Patzelt \& Shepherd, 2011; Shepherd \& Patzelt, 2011; see also Chap. 5). Taking this broader perspective, scholars can contribute to the current body of knowledge on the alleviation of suffering (broadly defined for the field but specifically defined in a single study) while simultaneously extending the boundaries of both entrepreneurship and positive organizational psychology.

\section{Future Research on Entrepreneurial Action to Alleviate the Suffering of Others}

Beyond the normal routines of established organizations. Although there are certain circumstances in which adapting an established organization's normal structures and routines can quite effectively alleviate human suffering (Dutton et al., 2006; Kanov et al., 2004), some events are likely to disable or obstruct these normal structures and routines (Drabek \& McEntire, 2003; Majchrzak, Jarvenpaa, \& Hollingshead, 2007). In this context, entrepreneurship scholars can shed light on the alleviation of suffering by exploring how, when, and why new ventures are created within or outside established organizations for the purpose of easing others' suffering (e.g., Miller, Grimes, McMullen, \& Vogus, 2012; Shepherd \& Williams, 2014; Williams \& Shepherd, 2017). It is important that we gain a deeper understanding of the factors that restrict or block an organization's normal routines from alleviating human suffering and both the 
motivations and the means some people have to start new ventures to alleviate human suffering. For example, why do some individuals start new ventures within established firms to alleviate others' suffering while others create new organizations to do so, why do these internal ventures emerge in some organizations but not in others, and why do some ventures solely focus on alleviating suffering while others focus on multiple objectives (e.g., earning profit and alleviating suffering) and to what effect? Ultimately, we are interested in why some entrepreneurial activities ease suffering more effectively than others and whose suffering is alleviated. This stream of research has the potential to extend the boundaries of compassion organizing theory and (hopefully) provide practical advice on how to help those who are suffering.

Alleviating the suffering of non-organizational members. Scholars have investigated how organizations effectively respond to their own organizational members' suffering (Dutton et al., 2006, p. 59; see also Dutton et al., 2014; Gittell, Cameron, Lim, \& Rivas, 2006; Powley, 2009; Rynes et al., 2012) because members of the same organization are more likely to detect (Powley, 2009) and empathize with a coworker's suffering (Lilius et al., 2011) while being close enough to act to alleviate that suffering (Dutton et al., 2006). Going beyond exploring suffering inside existing organizational boundaries, future research can explore how new ventures (within established organizations or entirely new organizations) are quickly and seemingly spontaneously formed to alleviate the suffering of individuals outside the responder's organization. Although we are beginning to gain a deeper understanding of why some individuals, groups, and/or organizations are capable of detecting and understanding others' (i.e., non-organizational members) suffering (Shepherd \& Williams, 2014) and why some are more effective at providing a more long-run solution to suffering (Williams \& Shepherd, 2017), we have barely scratched the surface of this important topic. Initial findings hint at the importance of the local community (Shepherd \& Williams, 2014; Williams \& Shepherd, 2017), but more needs to be done in exploring how to define, form, and lead communities in their compassionate endeavors. Specifically, what is the role of entrepreneurial action (and its underlying activities) in this community-creation process, and how does community formation in turn impact entrepreneurial action (in terms of a co-evolution).

Spontaneous venturing to alleviate others' suffering. While it generally takes time for a new organization to emerge (Katz \& Gartner, 1988; Liao, Welsch, \& Tan, 2005; Reynolds \& Miller, 1992), recent research has 
shown that new ventures can form almost immediately (in only hours or days) after an event that causes human suffering (Shepherd \& Williams, 2014; Williams \& Shepherd, 2017). Thus, it is important to understand how the venture-creation process is accelerated so quickly in this context. That is, how is the potential opportunity to ease others' suffering refined, what activities are involved in rapidly creating a new venture to alleviate suffering, which (if any) organizational-emergence activities are modified or simply omitted, and how are interactions between the entrepreneur and the various communities associated with the suffering (e.g., victims and suppliers) facilitated in such intense situations? This research is likely to advance our understanding of the many ways entrepreneurial action can ease others' suffering as well as offer a particularly fitting context for investigating organizational-emergence activities as the time required to follow and track those activities is considerably reduced in this context. (We also recognize the challenge of researching ventures formed in the immediate aftermath of a surprising event - the researcher is likely to find him- or herself among human suffering to study these activities.) If researchers can find a viable way to explore these spontaneous ventures, they are likely to uncover findings from these intense contexts that add to our understanding of organizational emergence in more traditional settings. For example, perhaps there are "spontaneous acts" in more traditional settings that precede later activities. If so, what form do these acts take; are such activities meant to be temporary, or are they probe-like actions used to provide immediate feedback; what are the motivations behind these actions, and what are the anticipated results; and what role (if any) does the government play in fostering compassion venturing?

Resourcefulness for compassionate responding. While existing conceptions of compassion generally stress that the more fortunate help the less fortunate (Dutton et al., 2006; Lilius et al., 2011), entrepreneurship scholars can add to our understanding of resourcefulness, such as bricolage (Baker \& Nelson, 2005), effectuation (Sarasvathy, 2001), improvisation (Baker et al., 2003; Hmieleski \& Corbett, 2008), identity (Powell \& Baker, 2014), entrepreneurial management (Bradley, Wiklund, \& Shepherd, 2011; Stevenson \& Jarillo, 1990), and knowledge corridors (Fiet, 2007; Fiet \& Samuelsson, 2000; Hayek, 1945), by exploring how resources are obtained, assembled, and recombined to alleviate specific types of suffering. This involves exploring how the less fortunate (i.e., those who are themselves suffering) take entrepreneurial actions to help the unfortunate (i.e., others who are suffering) and to what effect for the 
actor and the victims helped. How and why are some individuals who are themselves suffering and facing hardship able to act entrepreneurially to help others whereas some individuals are unable to do so? Research has also shown that locals (i.e., those living close to those suffering) are best positioned to help alleviate others' suffering as they are familiar with the region (i.e., Bui \& Sebastian, 2011; Quarantelli, 1993; Sebastian \& Bui, 2009) and have direct knowledge about the cause of the suffering as well as potential ways to ease it due to their strong understanding of the people involved and the local context (Sebastian \& Bui, 2009; Shepherd \& Williams, 2014; Waugh \& Streib, 2006; Williams \& Shepherd, 2017). However, it is likely that these locals are suffering themselves. What impact does helping alleviate others' suffering have on the entrepreneurial actor him- or herself? Interestingly, initial evidence suggests that victims of a natural disaster who act in the aftermath of that natural disaster by creating a new venture to alleviate others' suffering have better personal outcomes than those who do not act and that this gap in personal outcomes from those who create new ventures and those who do not is even greater for those with entrepreneurial experience (Williams \& Shepherd, 2016). However, more research is needed. For example, it is important to understand when entrepreneurial action in a disaster context leads to further personal risks and losses that could be detrimental to personal functioning (e.g., the failure of the new venture that creates increased feelings of loss; further shatters the individual's assumptions about the self, the world, and others; and drains all remaining resources) and the conditions under which entrepreneurial action serves as a form of coping for those who suffer (Shepherd, 2003) that leads to recovery (e.g., by distracting from the own suffering) or as the basis for resilience.

Prosocial motivation to act entrepreneurially to alleviate others' suffering. Not only do individuals need to be capable of acting to alleviate others' suffering, but they must also be motivated to do so. What factors motivate people to act entrepreneurially to ease others' suffering? Research grounded in the prosocial motivation literature will likely lead to fruitful explorations that can help answer this question. Prosocial motivation refers to individuals' desire to expend effort out of concern for helping or contributing to others (Batson, 1998; De Dreu, 2006; Grant, 2007, 2008; Grant \& Berry, 2011; Grant \& Sumanth, 2009) and can have numerous benefits for those being helped (Batson et al., 2008). Grant (2008, p. 49) explained that prosocial motivation is "a more temporary psychological state, [and it] involves a momentary focus on the goal of 
protecting and promoting the welfare of other people." While prosocial motivation is relatively under-researched, it appears to be a particularly important precursor to entrepreneurial actions that alleviate others' suffering (important exceptions include Miller et al., 2012; Renko, 2013).

Future research exploring the role of prosocial motivation compared to other forms of motivation in the compassionate venturing context is likely to make important contributions to the entrepreneurship literature. For example, prosocial motivation could compensate for a lack of intrinsic motivation in the creation of a new venture to alleviate others' suffering. If this is the case, what long-term effects on entrepreneurial activity would result from this motivational state? Perhaps being successful in alleviating others' suffering creates intrinsic motivation for the entrepreneurial tasks required in compassion venturing, or perhaps an initial lack of intrinsic motivation wears the entrepreneurial actor down, thus weakening the effect of prosocial motivation. If a lack of intrinsic motivation does wear the actor down, it is important to investigate what impact this reduced motivation has on the duration or development of compassion-oriented ventures. It could be that individuals need to develop other motivations to continue these ventures.

In addition to exploring these conjectures, investigating the possible shortcomings or boundaries of prosocial motivation in compassionate venturing is also likely to be important. Because prosocially motivated individuals are likely to view their work as a way to help others (Grant, 2007, 2008), this "ends justifies the means" approach to the alleviation of human suffering could have downsides. For example, there could be negative consequences for taking shortcuts to alleviate a particular group of individuals' suffering: maybe this aid comes at the expense of another group's suffering, perhaps it obstructs a greater (and perhaps more successful) effort to alleviate suffering, and/or perhaps it is a temporary solution that proves harmful in the long term. Indeed, perhaps the question is not whether it is good or bad to ignore constraints; rather, the question might be which constraints should be tolerated and which constraints should be overcome. In addition, exploring the ways potential resource providers come to notice, evaluate, and respond to prosocially motivated individuals who strive to alleviate others' suffering is also likely to provide interesting insights. How (if at all) do prosocially motivated entrepreneurial actors who try to alleviate others' suffering attract outside resource providers? What signals (if any) indicate prosocial motivation to outsiders, and how do outsiders respond to such signals? 


\section{Future Research}

Figure 2.4 illustrates some of the important aspects discussed above and provides a sketch of more compassionate and prosocial entrepreneurship research. Numerous research opportunities are imaginable from taking a more compassionate and prosocial perspective. However, we believe that exploring the following questions will lead to productive research: (1) how and why does awareness of others' suffering influence the formation of third- and/or first-person opportunity beliefs to do good, (2) how and why does prosocial motivation affect the formation of third- and/or firstperson opportunity beliefs to do good, (3) what characterizes entrepreneurial actions that exploit a potential opportunity to do good, (4) how and why do certain types of entrepreneurial action ease different kinds of suffering in others, $(5)$ how and why do different entrepreneurial actions lead to different societal benefits, (6) how does entrepreneurial action to ease suffering and/or improve sustainability influence the entrepreneur him- or herself, (7) how and why does progress in the entrepreneurial process (in terms of gains for others, the entrepreneur, and/or sustainability) influence the entrepreneur's knowledge (particularly knowledge of suffering) and motivation (particularly prosocial motivation and its interactions with intrinsic and extrinsic motivation) to form third- and/or first-person opportunity beliefs, (8) what other entrepreneurial activities influence the success of compassionate and sustainable venturing, and (9) what other forms of suffering can compassion venturing help overcome?

\section{Discussion And Conclusion}

There are inarguably numerous stimulating research opportunities that could advance our understanding of entrepreneurial phenomena, and we will illustrate many of them in the following chapters. In this chapter, we chose to focus on four avenues, offering a subset of potential conjectures within each avenue to inspire future work on the generation, refinement, and exploitation of potential opportunities. In doing so, we purposefully cast a wide net and went beyond what is considered a typical opportunity for profit by many scholars. Specifically, we believe future research can maintain the vitality of the field of entrepreneurship as well as advance knowledge by exploring (1) potential opportunities as social interactions between an entrepreneur's mind and a community of inquiry as well as the mutual adjustment between the two; (2) the antecedents, outcomes, and 


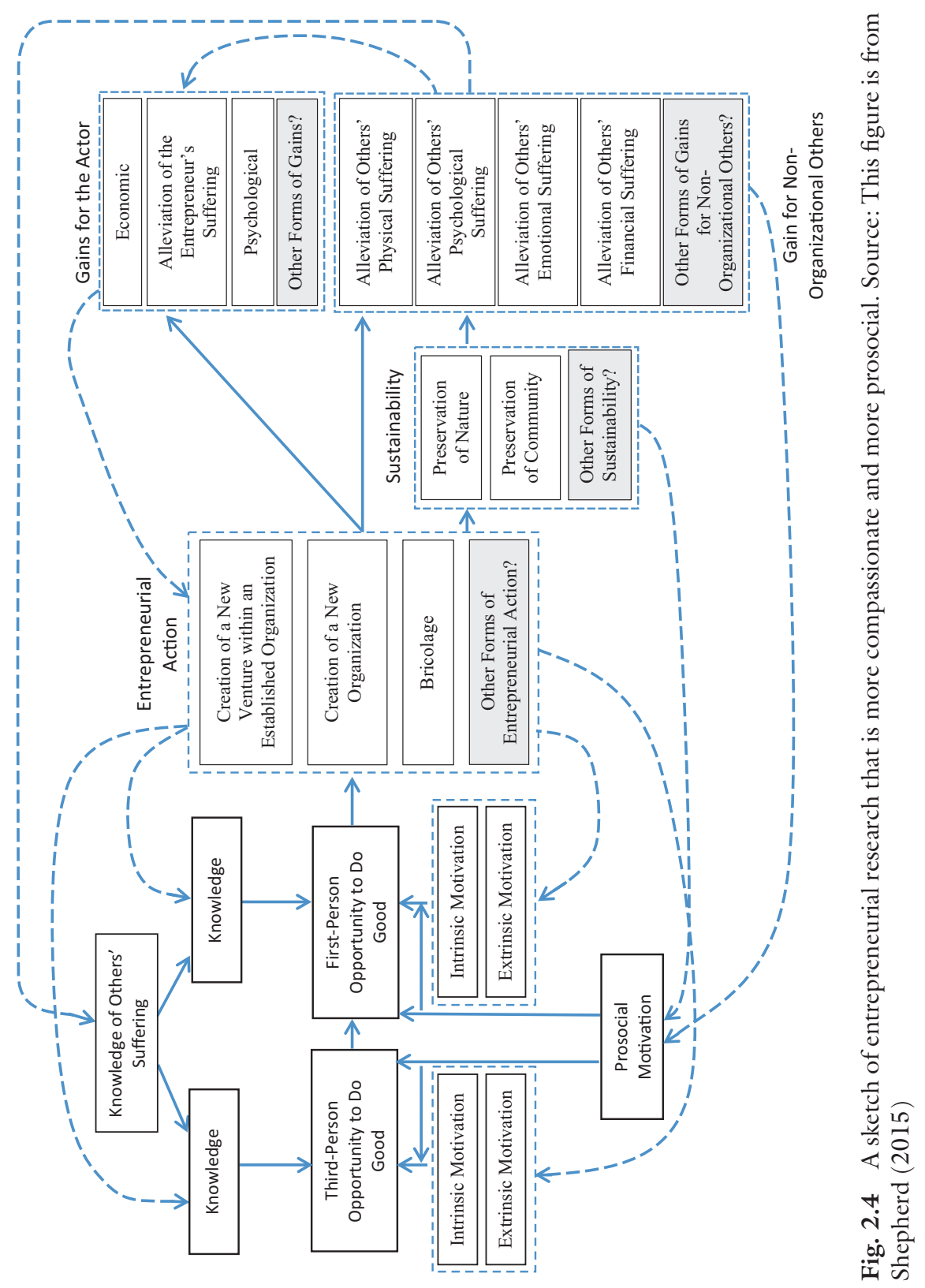


inter-relationships of activities as a micro-foundation of identifying, evaluating, and exploiting entrepreneurial opportunities; (3) the reciprocal relationships between cognition and emotion that are created, continued, and ended when an individual is engaged in the entrepreneurial process; and (4) the motivations and capabilities behind new venture creation (i.e., new organizations or new ventures in established organizations) that generate, evaluate, and exploit potential opportunities to do good.

Through these opportunities for future entrepreneurship research, we also want to challenge the way scholars engage in research-namely, we want to encourage scholars to go beyond studying entrepreneurial phenomena to engage in entrepreneurship research. Such research is possible when scholars (1) think entrepreneurially by keeping an open mind about new topics, methods, and ways of conducting research rather than focusing on one "right" or "traditional" approach; (2) think about interactions such that ideas become refined after interactions with communities of inquiry (e.g., colleagues, reviewers, editors, and so on) rather than focusing on the sole domain of their individual creativity; (3) think about the series of activities comprising their research by tending to the activities involved in developing a paper (i.e., the micro-foundations of research that we can control) and less on the overall outcomes of single projects or career milestones; (4) generate cognitive heat by remaining open to (or otherwise evoking) emotional reactions to interesting research activities and harnessing these emotions to invigorate and inform subsequent activities instead of taking a "cold" calculated approach to research, and (5) act prosocially to organize compassion venturing by selecting and exploring topics that will deepen our understanding of entrepreneurial actors who make helpful and/or harmful contributions to society as well as to help develop scholars who want to make a difference and/or are not as fortunate.

\section{REFERENCES}

Alvarez, S. A., \& Barney, J. B. (2007). Discovery and creation: Alternative theories of entrepreneurial action. Strategic Entrepreneurship Journal, 1(1-2), 11-26.

Alvarez, S. A., \& Busenitz, L. W. (2001). The entrepreneurship of resource-based theory. Journal of Management, 27(6), 755-775.

Ardichvili, A., Cardozo, R., \& Ray, S. (2003). A theory of entrepreneurial opportunity identification and development. Journal of Business Venturing, 18(1), $105-123$. 
Armstrong, K. (2011). Twelve steps to a compassionate life. Random House.

Ashforth, B. E., \& Kreiner, G. E. (2002). Normalizing emotion in organizations: Making the extraordinary seem ordinary. Human Resource Management Review, 12(2), 215-235.

Autio, E., Dahlander, L., \& Frederiksen, L. (2013). Information exposure, opportunity evaluation, and entrepreneurial action: An investigation of an online user community. Academy of Management Journal, 56(5), 1348-1371.

Baker, T., Miner, A. S., \& Eesley, D. T. (2003). Improvising firms: Bricolage, account giving and improvisational competencies in the founding process. Research Policy, 32(2), 255-276.

Baker, T., \& Nelson, R. E. (2005). Creating something from nothing: Resource construction through entrepreneurial bricolage. Administrative Science Quarterly, 50(3), 329-366.

Baldwin, C., Hienerth, C., \& Von Hippel, E. (2006). How user innovations become commercial products: A theoretical investigation and case study. Research Policy, 35(9), 1291-1313.

Baron, R. A. (2008). The role of affect in the entrepreneurial process. Academy of Management Review, 33(2), 328-340.

Baron, R. A., \& Ensley, M. D. (2006). Opportunity recognition as the detection of meaningful patterns: Evidence from comparisons of novice and experienced entrepreneurs. Management Science, 52(9), 1331-1344.

Batson, C. (1998). Altruism and prosocial behavior. In J. Y. Shah \& W. L. Gardner (Eds.), The Handbook of Social Psychology, 2, 463-484.

Batson, C. D., Ahmad, N., Powell, A. A., Stocks, E., Shah, J., \& Gardner, W. (2008). Prosocial motivation. Handbook of Motivation Science, 135-149.

Baumann, N., \& Kuhl, J. (2005). Positive affect and flexibility: Overcoming the precedence of global over local processing of visual information. Motivation and Emotion, 29(2), 123-134.

Belschak, F., Verbeke, W., \& Bagozzi, R. P. (2006). Coping with sales call anxiety: The role of sale perseverance and task concentration strategies. Journal of the Academy of Marketing Science, 34(3), 403-418.

Blanchette, I., \& Dunbar, K. (2001). Analogy use in naturalistic settings: The influence of audience, emotion, and goals. Memory \& Cognition, 29(5), 730-735.

Blood, A. J., \& Zatorre, R. J. (2001). Intensely pleasurable responses to music correlate with activity in brain regions implicated in reward and emotion. Proceedings of the National Academy of Sciences, 98, 11818-11823.

Bornstein, D. (2004). How to change the world: Social entrepreneurs and the power of new ideas. Oxford: Oxford University Press.

Bradley, S. W., Wiklund, J., \& Shepherd, D. A. (2011). Swinging a double-edged sword: The effect of slack on entrepreneurial management and growth. Journal of Business Venturing, 26(5), 537-554. 
Brettel, M., Mauer, R., Engelen, A., \& Küpper, D. (2012). Corporate effectuation: Entrepreneurial action and its impact on R\&D project performance. Journal of Business Venturing, 27(2), 167-184.

Brown, S. L., \& Eisenhardt, K. M. (1997). The art of continuous change: Linking complexity theory and time-paced evolution in relentlessly shifting organizations. Administrative Science Quarterly, 42, 1-34.

Brundin, E., Patzelt, H., \& Shepherd, D. A. (2008). Managers' emotional displays and employees' willingness to act entrepreneurially. Journal of Business Venturing, 23(2), 221-243.

Bruner, J. S. (1986). Actual minds, possible worlds. Cambridge, MA: Harvard University Press.

Bryant, P. (2007). Self-regulation and decision heuristics in entrepreneurial opportunity evaluation and exploitation. Management Decision, 45(4), 732-748.

Bui, T. X., \& Sebastian, I. (2011). Beyond rationality: Information design for supporting emergent groups in emergency response. In F. Burstein, P. Brézillon, \& A. Zaslavsky (Eds.), Supporting real time decision-making (pp. 159-179). Springer.

Burt, R. S. (2005). Brokerage and closure: An introduction to social capital. Oxford: Oxford University Press.

Busenitz, L. W., \& Barney, J. B. (1997). Differences between entrepreneurs and managers in large organizations: Biases and heuristics in strategic decisionmaking. Journal of Business Venturing, 12(1), 9-30.

Cardon, M. S., Foo, M. D., Shepherd, D., \& Wiklund, J. (2012). Exploring the heart: Entrepreneurial emotion is a hot topic. Entrepreneurship Theory and Practice, 36(1), 1-10.

Cardon, M. S., Wincent, J., Singh, J., \& Drnovsek, M. (2009). The nature and experience of entrepreneurial passion. Academy of Management Review, 34(3), 511-532.

Cardon, M. S., Zietsma, C., Saparito, P., Matherne, B. P., \& Davis, C. (2005). A tale of passion: New insights into entrepreneurship from a parenthood metaphor. Journal of Business Venturing, 20(1), 23-45.

Carter, N. M., Gartner, W. B., \& Reynolds, P. D. (1996). Exploring start-up event sequences. Journal of Business Venturing, 11(3), 151-166.

Catrambone, R., \& Holyoak, K. J. (1989). Overcoming contextual limitations on problem-solving transfer. Journal of Experimental Psychology: Learning, Memory, and Cognition, 15(6), 1147.

Chandra, Y., \& Coviello, N. (2010). Broadening the concept of international entrepreneurship: 'Consumers as international entrepreneurs'. Journal of World Business, 45(3), 228-236.

Corbett, A. C. (2005). Experiential learning within the process of opportunity identification and exploitation. Entrepreneurship Theory and Practice, 29(4), 473-491. 
Corbett, A. C., \& Hmieleski, K. M. (2007). The conflicting cognitions of corporate entrepreneurs. Entrepreneurship Theory and Practice, 31(1), 103-121.

Cornelissen, J. P., \& Clarke, J. S. (2010). Imagining and rationalizing opportunities: Inductive reasoning and the creation and justification of new ventures. Academy of Management Review, 35(4), 539-557.

Dacin, M. T., Dacin, P. A., \& Tracey, P. (2011). Social entrepreneurship: A critique and future directions. Organization Science, 22(5), 1203-1213.

Davidsson, P. (2003). The domain of entrepreneurship research: Some suggestions. Advances in Entrepreneurship, Firm Emergence and Growth, 6(3), 315-372.

Davidsson, P. (2015). Entrepreneurial opportunities and the entrepreneurship nexus: A re-conceptualization. Journal of Business Venturing, 30(5), 674-695.

Davidsson, P., \& Gordon, S. R. (2012). Panel studies of new venture creation: A methods-focused review and suggestions for future research. Small Business Economics, 39(4), 853-876.

Davidsson, P., \& Honig, B. (2003). The role of social and human capital among nascent entrepreneurs. Journal of Business Venturing, 18(3), 301-331.

De Dreu, C. K. (2006). When too little or too much hurts: Evidence for a curvilinear relationship between task conflict and innovation in teams. Journal of Management, 32(1), 83-107.

Dean, T. J., \& McMullen, J. S. (2007). Toward a theory of sustainable entrepreneurship: Reducing environmental degradation through entrepreneurial action. Journal of Business Venturing, 22(1), 50-76.

Dees, J. G. (1998). The meaning of social entrepreneurship. Working paper.

Delmar, F., \& Shane, S. (2004). Legitimating first: Organizing activities and the survival of new ventures. Journal of Business Venturing, 19(3), 385-410.

Derryberry, D., \& Tucker, D. (2006). Motivation, self-regulation, and selforganization. Developmental Psychopathology, 2, 502-532.

Dewey, J. (1939). Theory of valuation. International Encyclopedia of Unified Science, 2(4), vii-v67.

Dimov, D. (2007). Beyond the single-person, single-insight attribution in understanding entrepreneurial opportunities. Entrepreneurship Theory and Practice, $31(5), 713-731$.

Dimov, D. (2011). Grappling with the unbearable elusiveness of entrepreneurial opportunities. Entrepreneurship Theory and Practice, 35(1), 57-81.

Dorado, S., \& Ventresca, M. J. (2013). Crescive entrepreneurship in complex social problems: Institutional conditions for entrepreneurial engagement. Journal of Business Venturing, 28(1), 69-82.

Dorfman, R., \& Dorfman, N. S. (1993). Economics of the environment: Selected readings. WW Norton \& Company.

Drabek, T. E., \& McEntire, D. A. (2003). Emergent phenomena and the sociology of disaster: Lessons, trends and opportunities from the research literature. Disaster Prevention and Management, 12(2), 97-112. 
Dutton, J. E. (1993). Interpretations on automatic: A different view of strategic issue diagnosis. Journal of Management Studies, 30(3), 339-357.

Dutton, J. E. (2003). Breathing life into organizational studies. Journal of Management Inquiry, 12(1), 5-19.

Dutton, J. E., \& Duncan, R. B. (1987). The creation of momentum for change through the process of strategic issue diagnosis. Strategic Management Journal, $8(3), 279-295$.

Dutton, J. E., Workman, K. M., \& Hardin, A. E. (2014). Compassion at work. Annual Review of Organizational Psychology and Organizational Behavior, 1, 277-304.

Dutton, J. E., Worline, M. C., Frost, P. J., \& Lilius, J. (2006). Explaining compassion organizing. Administrative Science Quarterly, 51(1), 59-96.

Eisenhardt, K. M. (1989). Making fast strategic decisions in high-velocity environments. Academy of Management Journal, 32(3), 543-576.

Estrada, C. A., Isen, A. M., \& Young, M. J. (1997). Positive affect facilitates integration of information and decreases anchoring in reasoning among physicians. Organizational Behavior and Human Decision Processes, 72(1), 117-135.

Fiet, J. O. (2007). A prescriptive analysis of search and discovery. Journal of Management Studies, 44(4), 592-611.

Fiet, J. O., \& Samuelsson, M. (2000). Knowledge-based competencies as a platform for firm formation. Frontiers of Entrepreneurship Research, 166-178.

Fitzsimmons, J. R., \& Douglas, E. J. (2011). Interaction between feasibility and desirability in the formation of entrepreneurial intentions. Journal of Business Venturing, 26(4), 431-440.

Foo, M. D. (2011). Emotions and entrepreneurial opportunity evaluation. Entrepreneurship Theory and Practice, 35(2), 375-393.

Foo, M.-D., Uy, M. A., \& Baron, R. A. (2009). How do feelings influence effort? An empirical study of entrepreneurs' affect and venture effort. Journal of Applied Psychology, 94(4), 1086.

Forbes, D. P. (2005). Are some entrepreneurs more overconfident than others? Journal of Business Venturing, 20(5), 623-640.

Foss, K., Foss, N. J., Klein, P. G., \& Klein, S. K. (2007). The entrepreneurial organization of heterogeneous capital. Journal of Management Studies, 44, 1165-1186.

Fredrickson, B. L. (1998). What good are positive emotions? Review of General Psychology, 2(3), 300-319.

Fredrickson, B. L. (2000). Cultivating positive emotions to optimize health and well-being. Prevention \& Treatment, 3(1), la.

Fredrickson, B. L. (2001). The role of positive emotions in positive psychology: The broaden-and-build theory of positive emotions. American Psychologist, $56(3), 218-226$.

Fredrickson, B. L., \& Branigan, C. (2005). Positive emotions broaden the scope of attention and thought-action repertoires. Cognition \& Emotion, 19(3), 313-332. 
Fredrickson, B. L., Cohn, M. A., Coffey, K. A., Pek, J., \& Finkel, S. M. (2008). Open hearts build lives: Positive emotions, induced through loving-kindness meditation, build consequential personal resources. Journal of Personality and Social Psychology, 95(5), 1045.

Fredrickson, B. L., Mancuso, R. A., Branigan, C., \& Tugade, M. M. (2000). The undoing effect of positive emotions. Motivation and Emotion, 24(4), 237-258.

Frost, P. J. (2003). Toxic emotions at work: How compassionate managers handle pain and conflict. Boston, MA: Harvard Business School Publishing.

Gaglio, C. M., \& Katz, J. A. (2001). The psychological basis of opportunity identification: Entrepreneurial alertness. Small Business Economics, 16(2), 95-111.

Gartner, W. B. (1985). A conceptual framework for describing the phenomenon of new venture creation. Academy of Management Review, 10(4), 696-706.

Gartner, W. B., Carter, N. M., \& Hills, G. E. (2003). The language of opportunity. In C. Steyaert \& D. Hjorth (Eds.), New movements in entrepreneurship (pp. 103-124). Edward Elgar Publishing Limited.

Gergen, K. J. (1994). Realities and relationships: Soundings in social construction. Cambridge, MA: Harvard University Press.

George, J. M. (2013). Compassion and capitalism implications for organizational studies. Journal of Management. Advance online publication.

Gielnik, M. M., Spitzmuller, M., Schmitt, A., Klemann, D. K., \& Frese, M. (2015). "I put in effort, therefore I am passionate": Investigating the path from effort to passion in entrepreneurship. Academy of Management Journal, 58(4), 1012-1031.

Gittell, J. H., Cameron, K., Lim, S., \& Rivas, V. (2006). Relationships, layoffs, and organizational resilience airline industry responses to September 11. Journal of Applied Behavioral Science, 42(3), 300-329.

Grant, A. M. (2007). Relational job design and the motivation to make a prosocial difference. Academy of Management Review, 32(2), 393-417.

Grant, A. M. (2008). Does intrinsic motivation fuel the prosocial fire? Motivational synergy in predicting persistence, performance, and productivity. Journal of Applied Psychology, 93(1), 48.

Grant, A. M., \& Berry, J. W. (2011). The necessity of others is the mother of invention: Intrinsic and prosocial motivations, perspective taking, and creativity. Academy of Management Journal, 54(1), 73-96.

Grant, A. M., \& Sumanth, J. J. (2009). Mission possible? The performance of prosocially motivated employees depends on manager trustworthiness. Journal of Applied Psychology, 94(4), 927.

Grégoire, D. A., Barr, P. S., \& Shepherd, D. A. (2010). Cognitive processes of opportunity recognition: The role of structural alignment. Organization Science, 21(2), 413-431. 
Grégoire, D. A., \& Shepherd, D. A. (2012). Technology-market combinations and the identification of entrepreneurial opportunities: An investigation of the opportunity-individual nexus. Academy of Management Journal, 55(4), 753-785.

Gregoire, D. A., Corbett, A. C., \& McMullen, J. S. (2011). The cognitive perspective in entrepreneurship: An agenda for future research. Journal of Management Studies, 48(6), 1443-1477.

Grichnik, D., Smeja, A., \& Welpe, I. (2010). The importance of being emotional: How do emotions affect entrepreneurial opportunity evaluation and exploitation? Journal of Economic Behavior \& Organization, 76(1), 15-29.

Gruber, M., MacMillan, I. C., \& Thompson, J. D. (2013). Escaping the prior knowledge corridor: What shapes the number and variety of market opportunities identified before market entry of technology start-ups? Organization Science, 24(1), 280-300.

Haefliger, S., Jäger, P., \& Von Krogh, G. (2010). Under the radar: Industry entry by user entrepreneurs. Research Policy, 39(9), 1198-1213.

Hall, J. K., Daneke, G. A., \& Lenox, M. J. (2010). Sustainable development and entrepreneurship: Past contributions and future directions. Journal of Business Venturing, 25(5), 439-448.

Haskel, T. (1984). Professionalism versus capitalism: R. H. Tawney, Emile Durkheim, and C.S. Pierce on the disinterestedness of professional communities. In T. Haskel (Ed.), The authority of experts: Studies in history and theory (pp. 180-225). Bloomington, IN: Indiana University Press.

Hayek, F. A. (1945). The use of knowledge in society. The American Economic Review, 35, 519-530.

Haynie, J. M., Shepherd, D. A., \& McMullen, J. S. (2009). An opportunity for me? The role of resources in opportunity evaluation decisions. Journal of Management Studies, 46(3), 337-361.

Haynie, J. M., Shepherd, D. A., Mosakowski, E., \& Earley, P. C. (2010). A situated metacognitive model of the entrepreneurial mindset. Journal of Business Venturing, 25(2), 217-229.

Hill, R. C., \& Levenhagen, M. (1995). Metaphors and mental models: Sensemaking and sensegiving in innovative and entrepreneurial activities. Journal of Management, 21(6), 1057-1074.

Hite, J. M. (2005). Evolutionary processes and paths of relationally embedded network ties in emerging entrepreneurial firms. Entrepreneurship Theory and Practice, 29(1), 113-144.

Hmieleski, K. M., \& Baron, R. A. (2008). Regulatory focus and new venture performance: A study of entrepreneurial opportunity exploitation under conditions of risk versus uncertainty. Strategic Entrepreneurship Journal, 2(4), 285-299.

Hmieleski, K. M., \& Corbett, A. C. (2008). The contrasting interaction effects of improvisational behavior with entrepreneurial self-efficacy on new venture performance and entrepreneur work satisfaction. Journal of Business Venturing, 23(4), 482-496. 
Hoang, H., \& Antoncic, B. (2003). Network-based research in entrepreneurship: A critical review. Journal of Business Venturing, 18(2), 165-187.

Holland, J., Holyoak, K., Nisbett, R., \& Thagard, P. (1986). Process of inference, learning, and discovery. Cambridge, MA: MIT Press.

Holyoak, K. J., \& Thagard, P. (1995). Mental leaps. Cambridge, MA: MIT Press.

Isen, A. M., \& Daubman, K. A. (1984). The influence of affect on categorization. Journal of Personality and Social Psychology, 47(6), 1206.

Isen, A. M., Daubman, K. A., \& Nowicki, G. P. (1987). Positive affect facilitates creative problem solving. Journal of Personality and Social Psychology, 52(6), $1122-1131$.

Kanov, J. M., Maitlis, S., Worline, M. C., Dutton, J. E., Frost, P. J., \& Lilius, J. M. (2004). Compassion in organizational life. American Behavioral Scientist, $47(6), 808-827$.

Katz, J., \& Gartner, W. B. (1988). Properties of emerging organizations. Academy of Management Review, 13(3), 429-441.

Keane, M. T., Ledgeway, T., \& Duff, S. (1994). Constraints on analogical mapping: A comparison of three models. Cognitive Science, 18(3), 387-438.

Keh, H. T., Foo, M. D., \& Lim, B. C. (2002). Opportunity evaluation under risky conditions: The cognitive processes of entrepreneurs. Entrepreneurship Theory and Practice, 27(2), 125-148.

Khan, F. R., Munir, K. A., \& Willmott, H. (2007). A dark side of institutional entrepreneurship: Soccer balls, child labour and postcolonial impoverishment. Organization Studies, 28(7), 1055-1077.

Kim, P. H., Longest, K. C., \& Lippmann, S. (2015). The tortoise versus the hare: Progress and business viability differences between conventional and leisurebased founders. Journal of Business Venturing, 30(2), 185-204.

Klein, P. G. (2008). Opportunity discovery, entrepreneurial action, and economic organization. Strategic Entrepreneurship Journal, 2(3), 175-190.

Klofsten, M. (2005). New venture ideas: An analysis of their origin and early development. Technology Analysis and Strategic Management, 17(1), 105-119.

Kloppenberg, J. T. (1989). Objectivity and historicism: A century of American historical writing. American Historical Review, 94(4), 1011-1030.

Knight, F. H. (1921). Risk, uncertainty and profit. New York: Hart, Schaffner and Marx.

Krueger Jr., N. F. (2003). The cognitive psychology of entrepreneurship, Handbook of entrepreneurship research (pp. 105-140). New York: Springer.

Krueger, N. F. (2007). What lies beneath? The experiential essence of entrepreneurial thinking. Entrepreneurship Theory and Practice, 31(1), 123-138.

Kuratko, D. F., Hornsby, J. S., \& Covin, J. G. (2014). Diagnosing a firm's internal environment for corporate entrepreneurship. Business Horizons, 57(1), 37-47.

Liao, J., Welsch, H., \& Tan, W.-L. (2005). Venture gestation paths of nascent entrepreneurs: Exploring the temporal patterns. Journal of High Technology Management Research, 16(1), 1-22. 
Lichtenstein, B. B., Carter, N. M., Dooley, K. J., \& Gartner, W. B. (2007). Complexity dynamics of nascent entrepreneurship. Journal of Business Venturing, 22(2), 236-261.

Lilius, J. M., Worline, M. C., Dutton, J. E., Kanov, J. M., \& Maitlis, S. (2011). Understanding compassion capability. Human Relations, 64(7), 873-899.

Lilius, J. M., Worline, M. C., Maitlis, S., Kanov, J., Dutton, J. E., \& Frost, P. (2008). The contours and consequences of compassion at work. Journal of Organizational Behavior, 29(2), 193-218.

Locke, K., Golden-Biddle, K., \& Feldman, M. S. (2008). Perspective-making doubt generative: Rethinking the role of doubt in the research process. Organization Science, 19(6), 907-918.

Lumpkin, G. T., \& Dess, G. G. (1996). Clarifying the entrepreneurial orientation construct and linking it to performance. Academy of Management Review, $21(1), 135-172$.

Maffei, L., \& Fiorentini, A. (1995). Art and brain. Bologna: Zanichelli.

Mair, J., \& Marti, I. (2006). Social entrepreneurship research: A source of explanation, prediction, and delight. Journal of World Business, 4l(1), 36-44.

Majchrzak, A., Jarvenpaa, S. L., \& Hollingshead, A. B. (2007). Coordinating expertise among emergent groups responding to disasters. Organization Science, 18(1), 147-161.

McGrath, R. G. (1999). Falling forward: Real options reasoning and entrepreneurial failure. Academy of Management Review, 24(1), 13-30.

McKelvie, A., Haynie, J. M., \& Gustavsson, V. (2011). Unpacking the uncertainty construct: Implications for entrepreneurial action. Journal of Business Venturing, 26(3), 273-292.

McMullen, J. S. (2011). Delineating the domain of development entrepreneurship: A market-based approach to facilitating inclusive economic growth. Entrepreneurship Theory and Practice, 35(1), 185-193.

McMullen, J. S., \& Dimov, D. (2013). Time and the entrepreneurial journey: The problems and promise of studying entrepreneurship as a process. Journal of Management Studies, 50(8), 1481-1512.

McMullen, J. S., Plummer, L. A., \& Acs, Z. J. (2007). What is an entrepreneurial opportunity? Small Business Economics, 28(4), 273-283.

McMullen, J. S., \& Shepherd, D. A. (2006). Entrepreneurial action and the role of uncertainty in the theory of the entrepreneur. Academy of Management Review, 31(1), 132-152.

Meek, W. R., Pacheco, D. F., \& York, J. G. (2010). The impact of social norms on entrepreneurial action: Evidence from the environmental entrepreneurship context. Journal of Business Venturing, 25(5), 493-509.

Miller, T. L., Grimes, M. G., McMullen, J. S., \& Vogus, T. J. (2012). Venturing for others with heart and head: How compassion encourages social entrepreneurship. Academy of Management Review, 37(4), 616-640. 
Mitchell, J. R., \& Shepherd, D. A. (2010). To thine own self be true: Images of self, images of opportunity, and entrepreneurial action. Journal of Business Venturing, 25(1), 138-154.

Mitchell, R. K., Smith, J. B., Morse, E. A., Seawright, K. W., Peredo, A. M., \& McKenzie, B. (2002). Are entrepreneurial cognitions universal? Assessing entrepreneurial cognitions across cultures. Entrepreneurship Theory and Practice, 26(4), 9-32.

Mitchell, R. K., Smith, B., Seawright, K. W., \& Morse, E. A. (2000). Crosscultural cognitions and the venture creation decision. Academy of Management Journal, 43(5), 974-993.

Paavola, S. (2004). Abduction as a logic and methodology of discovery: The importance of strategies. Foundations of Science, 9(3), 267-283.

Pardales, M. J., \& Girod, M. (2006). Community of Inquiry: Its past and present future. Educational Philosophy and Theory, 38(3), 299-309.

Patzelt, H., \& Shepherd, D. A. (2011). Recognizing opportunities for sustainable development. Entrepreneurship Theory and Practice, 35(4), 631-652.

Peirce, C. S. (1955). Philosophical writings of Peirce. Courier Dover Publications.

Peredo, A. M., \& Chrisman, J. J. (2006). Toward a theory of community-based enterprise. Academy of Management Review, 31(2), 309-328.

Powell, E. E., \& Baker, T. (2014). It's what you make of it: Founder identity and enacting strategic responses to adversity. Academy of Management Journal, $7(5), 1406-1433$.

Powley, E. H. (2009). Reclaiming resilience and safety: Resilience activation in the critical period of crisis. Human Relations, 62(9), 1289-1326.

Prawat, R. S. (1995). Misreading Dewey: Reform, projects, and the language game. Educational Researcher, 24(7), 13-22.

Quarantelli, E. L. (1993). Community crises: An exploratory comparison of the characteristics and consequences of disasters and riots. Journal of Contingencies and Crisis Management, 1(2), 67-78.

Renko, M. (2013). Early challenges of nascent social entrepreneurs. Entrepreneurship Theory and Practice, 37(5), 1045-1069.

Reynolds, P., \& Miller, B. (1992). New firm gestation: Conception, birth, and implications for research. Journal of Business Venturing, 7(5), 405-417.

Roberts, D., \& Woods, C. (2005). Changing the world on a shoestring: The concept of social entrepreneurship. University of Auckland Business Review, 7, 45-51.

Russell, J. A. (2003). Core affect and the psychological construction of emotion. Psychological Review, 110(1), 145-172.

Russell, P., \& Milne, S. (1997). Meaningfulness and hedonic value of paintings: Effects of titles. Empirical Studies of the Arts, 15(1), 61-73.

Rynes, S., Bartunek, J., Dutton, J., \& Margolis, J. (2012). Care and compassion through an organizational lens: Opening up new possibilities. Academy of Management Review, 37(4), 503-523. 
Sarasvathy, S. D. (2001). Causation and effectuation: Toward a theoretical shift from economic inevitability to entrepreneurial contingency. Academy of Management Review, 26(2), 243-263.

Sarasvathy, S. D., Dew, N., Velamuri, S. R., \& Venkataraman, S. (2010). Three views of entrepreneurial opportunity. In Handbook of entrepreneurship research (pp. 77-96). Springer.

Schneider, I. K., Eerland, A., van Harreveld, F., Rotteveel, M., van der Pligt, J., Van der Stoep, N., et al. (2013). One way and the other the bidirectional relationship between ambivalence and body movement. Psychological Science, 24(3), 319-325.

Schuler, S. R., Hashemi, S. M., \& Badal, S. H. (1998). Men's violence against women in rural Bangladesh: Undermined or exacerbated by microcredit programmes? Development in Practice, 8(2), 148-157.

Sebastian, I. M., \& Bui, T. X. (2009). Emergent groups for emergency responsetheoretical foundations and information design implications. AMCIS 2009 Proceedings, 638, 1-9.

Seixas, P. (1993). The community of inquiry as a basis for knowledge and learning: The case of history. American Educational Research Journal, 30(2), 305-324.

Seligman, M. E., \& Csikszentmihalyi, M. (2000). Positive psychology: An introduction. American Psychological Association.

Seligman, M. E., Steen, T. A., Park, N., \& Peterson, C. (2005). Positive psychology progress: Empirical validation of interventions. American Psychologist, 60(5), 410.

Shah, S. K., \& Tripsas, M. (2007). The accidental entrepreneur: The emergent and collective process of user entrepreneurship. Strategic Entrepreneurship Journal, 1(1-2), 123-140.

Shalley, C. E., \& Perry-Smith, J. E. (2008). The emergence of team creative cognition: The role of diverse outside ties, sociocognitive network centrality, and team evolution. Strategic Entrepreneurship Journal, 2(1), 23-41.

Shane, S. (2000). Prior knowledge and the discovery of entrepreneurial opportunities. Organization Science, 11(4), 448-469.

Shane, S., \& Eckhardt, J. (2003). The individual-opportunity nexus. In Handbook of entrepreneurship research (pp. 161-191). Springer.

Shanley, J. P. (2005). Doubt: A parable. New York: Dramatists Play Service, Inc.

Shepherd, D. A. (2003). Learning from business failure: Propositions of grief recovery for the self-employed. Academy of Management Review, 28(2), 318-328.

Shepherd, D. A., \& DeTienne, D. R. (2005). Prior knowledge, potential financial reward, and opportunity identification. Entrepreneurship Theory and Practice, 29(1), 91-112.

Shepherd, D. A., Haynie, J. M., \& McMullen, J. S. (2012). Confirmatory search as a useful heuristic? Testing the veracity of entrepreneurial conjectures. Journal of Business Venturing, 27(6), 637-651.

Shepherd, D. A., McMullen, J. S., \& Jennings, P. D. (2007). The formation of opportunity beliefs: Overcoming ignorance and reducing doubt. Strategic Entrepreneurship Journal, 1(1-2), 75-95. 
Shepherd, D. A., \& Patzelt, H. (2011). The new field of sustainable entrepreneurship: Studying entrepreneurial action linking "what is to be sustained" with "what is to be developed". Entrepreneurship Theory and Practice, 35(1), 137-163.

Shepherd, D., Patzelt, H., \& Baron, R. (2013). "I care about nature, but ...": Disengaging values in assessing opportunities that cause harm. Academy of Management Journal, 56(5), 1251-1273.

Shepherd, D. A., Patzelt, H., Williams, T. A., \& Warnecke, D. (2014). How does project termination impact project team members? Rapid termination, 'creeping death', and learning from failure. Journal of Management Studies, 51(4), 513-546.

Shepherd, D. A., Patzelt, H., \& Wolfe, M. (2011). Moving forward from project failure: Negative emotions, affective commitment, and learning from the experience. Academy of Management Journal, 54(6), 1229-1259.

Shepherd, D. A. (2015). Party On! A call for entrepreneurship research that is more interactive, activity based, cognitively hot, compassionate, and prosocial. Journal of Business Venturing, 30(4), 489-507.

Shepherd, D. A., \& Williams, T. A. (2014). Local venturing as compassion organizing in the aftermath of a natural disaster: The role of localness and community in reducing suffering. Journal of Management Studies, 51(6), 952-994.

Short, J. C., Ketchen, D. J., Shook, C. L., \& Ireland, R. D. (2009). The concept of "opportunity" in entrepreneurship research: Past accomplishments and future challenges. Journal of Management, 36(1), 40-65.

Smith, J. B., Mitchell, J. R., \& Mitchell, R. K. (2009). Entrepreneurial scripts and the new transaction commitment mindset: Extending the expert information processing theory approach to entrepreneurial cognition research. Entrepreneurship Theory and Practice, 33(4), 815-844.

Sorenson, O., \& Audia, P. G. (2000). The social structure of entrepreneurial activity: Geographic concentration of footwear production in the United States, 1940-1989. American Journal of Sociology, 106(2), 424-462.

Stevenson, H. H., \& Jarillo, J. C. (1990). A paradigm of entrepreneurship: Entrepreneurial management. Strategic Management Journal, 11, 17-27.

Stinchfield, B. T., Nelson, R. E., \& Wood, M. S. (2013). Learning from LeviStrauss' legacy: Art, craft, engineering, bricolage, and brokerage in entrepreneurship. Entrepreneurship Theory and Practice, 37(4), 889-921.

Sutcliffe, K., \& Vogus, T. J. (2003). Organizing for resilience. Positive Organizational Scholarship: Foundations of a New Discipline, 94, 110.

Swedberg, R. (2009). Schumpeter's full model of entrepreneurship. In R. Ziegler (Ed.), An introduction to social entrepreneurship: Voices, preconditions, contexts (pp. 77-106). Cheltenham, UK: Edward Elgar.

Tang, J., Kacmar, K. M., \& Busenitz, L. (2012). Entrepreneurial alertness in the pursuit of new opportunities. Journal of Business Venturing, 27(1), 77-94.

Tietenberg, T. (2000). Environmental and natural resource economics. New York: Addison Wesley.

Tripsas, M., \& Gavetti, G. (2000). Capabilities, cognition, and inertia: Evidence from digital imaging. Strategic Management Journal, 21(10-11), 1147-1161. 
Ucbasaran, D., Westhead, P., \& Wright, M. (2008). Opportunity identification and pursuit: Does an entrepreneur's human capital matter? Small Business Economics, 30(2), 153-173.

Waugh, C. E., \& Fredrickson, B. L. (2006). Nice to know you: Positive emotions, self-other overlap, and complex understanding in the formation of a new relationship. The Journal of Positive Psychology, 1(2), 93-106.

Waugh, W. L., \& Streib, G. (2006). Collaboration and leadership for effective emergency management. Public Administration Review, 66(s1), 131-140.

Welpe, I. M., Spörrle, M., Grichnik, D., Michl, T., \& Audretsch, D. B. (2012). Emotions and opportunities: The interplay of opportunity evaluation, fear, joy, and anger as antecedent of entrepreneurial exploitation. Entrepreneurship Theory and Practice, 36(1), 69-96.

West, G. P. (2007). Collective cognition: When entrepreneurial teams, not individuals, make decisions. Entrepreneurship Theory and Practice, 31(1), 77-102.

Williams, T. A., \& Shepherd, D. A. (2016). Victim entrepreneurs doing well by doing good: Venture creation and well-being in the aftermath of a resource shock. Journal of Business Venturing, 31(4), 365-387.

Williams, T., \& Shepherd, D. (2017). Building resilience or providing sustenance: Different paths of emergent ventures in the aftermath of the haiti earthquake. Academy of Management Journal. Forthcoming.

Wilson, E. B. (1990). An introduction to scientific research. Courier Dover Publications.

Yli-Renko, H., Autio, E., \& Sapienza, H. J. (2001). Social capital, knowledge acquisition, and knowledge exploitation in young technology-based firms. Strategic Management Journal, 22(6-7), 587-613.

York, J. G., \& Venkataraman, S. (2010). The entrepreneur-environment nexus: Uncertainty, innovation, and allocation. Journal of Business Venturing, 25(5), 449-463.

Zahra, S. A., Rawhouser, H. N., Bhawe, N., Neubaum, D. O., \& Hayton, J. C. (2008). Globalization of social entrepreneurship opportunities. Strategic Entrepreneurship Journal, 2(2), 117-131.

Open Access This chapter is distributed under the terms of the Creative Commons Attribution 4.0 International License (http://creativecommons.org/licenses/by/4.0/), which permits use, duplication, adaptation, distribution and reproduction in any medium or format, as long as you give appropriate credit to the original author(s) and the source, provide a link to the Creative Commons license and indicate if changes were made.

The images or other third party material in this chapter are included in the work's Creative Commons license, unless indicated otherwise in the credit line; if such material is not included in the work's Creative Commons license and the respective action is not permitted by statutory regulation, users will need to obtain permission from the license holder to duplicate, adapt or reproduce the material.

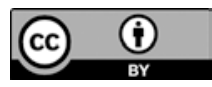

